\title{
Solution equilibria studies of complexes of divalent metal ions with 2-aminophenol and 3,4-dihydroxybenzoic acid
}

\author{
Ivon Kusmijo Chandra ${ }^{a}$, Artik Elisa Angkawijaya ${ }^{a}$, Shella Permatasari Santoso ${ }^{a}$, Suryadi Ismadji ${ }^{\text {, }}$, \\ Felycia Edi Soetaredjo $^{\mathrm{b}}$, Yi-Hsu Ju ${ }^{\mathrm{a}, *}$ \\ a Chemical Engineering Department, National Taiwan University of Science and Technology, Taipei 106-07, Taiwan \\ ${ }^{\mathrm{b}}$ Department of Chemical Engineering, Widya Mandala Surabaya Catholic University, Kalijudan 37, Surabaya 60114, Indonesia
}

\section{A R T I C L E I N F O}

\section{Article history:}

Received 1 August 2014

Accepted 28 November 2014

Available online 27 December 2014

\section{Keywords:}

3,4-Dihydroxybenzoic acid

2-Aminophenol

pH-potentiometry

Hyperquad 2008

UV-Vis spectrophotometry

\begin{abstract}
A B S T R A C T
The chelation abilities of 2-aminophenol and 3,4-dihydroxybenzoic acid with divalent metal ions $\mathrm{C}^{2+}$, $\mathrm{Be}^{2+}, \mathrm{Zn}^{2+}, \mathrm{Ni}^{2+}, \mathrm{Co}^{2+}$ and $\mathrm{Mn}^{2+}$ ) in binary and ternary systems at $37 \pm 0.1^{\circ} \mathrm{C}$ and an ionic strength of $0.15 \mathrm{~mol} \mathrm{dm}^{-3} \mathrm{NaCl}$ were systematically investigated by using the potentiometric titration method. The chelating abilities of these complexes were obtained by processing the titration data using the Hyperquad2008 program and the results are presented as stability constants. In a binary system, it was shown that metal complexation involving 3,4-dihydroxybenzoic acid (ligand $\mathrm{D}$ ) is more stable than the one with 2-aminophenol (ligand A). The stability of the formed metal complexes, both in binary and ternary systems, decreases in the following order: $\mathrm{Cu}^{2+}>\mathrm{Be}^{2+}>\mathrm{Zn}^{2+}>\mathrm{Ni}^{2+}>\mathrm{Co}^{2+}>\mathrm{Mn}^{2+}$. The tendency of these metals and ligands to form binary or ternary complexes was also evaluated and discussed by calculating their $\Delta \log K_{\mathrm{M}}$ and $\log X$ values. In addition, the distribution of complex species in these systems was graphically presented using the HySS2009 program. UV-Vis spectrophotometry was also performed to qualitatively verify the protonation of these ligands and to confirm the model of the complex formed.
\end{abstract}

(c) 2014 Elsevier Ltd. All rights reserved.

\section{Introduction}

The earth is rich in various metals which are distinguished by their electronic distributions, that in turn affect their physiological and pathological characteristics. Several metals, which are part of dietary minerals, are found in every living organism and they take part in the functionality of body systems; in particular as stabilizers of biological structures, components of control mechanism (in nerves and muscles) and activators or components of redox systems $[1,2]$. In other words, some metals are categorized as essential elements, meaning the lack of them will affect the biological functions of the human body. In contrast, their presence in excess levels is toxic and may have adverse effects on human health.

Chelation therapy has been known as one of the medical treatments that is able to reduce excess metal levels in the human body and indirectly prevent carcinogenesis and cancer development. This therapy has been applied historically and it commonly employs certain chelating agents to reduce the body's burden

\footnotetext{
* Corresponding author at: Chemical Engineering Department, National Taiwan University of Science and Technology, 43 Keelung Road, Section 4, Taipei 106-07, Taiwan.

E-mail address: yhju@mail.ntust.edu.tw (Y.-H. Ju).
}

towards metal toxicity [3-5]. However, commercial chelators still bring some adverse effects and it sometimes leads to death [1,6-9]. Several new potential chelators, including vitamin, phenolic compounds and amino acids, are found to increase metal mobilization, which means they could minimize the possibility of the interaction of the metal ions with important bio-substances [10-12]. Several studies have reported that combining a chelating agent and an antioxidant may be beneficial for metal poisoning antidote therapy, by protecting the human body from reactive oxygen species and oxidative stress $[1,12,13]$.

In this study, two phenolic compounds (2-aminophenol and 3,4-dihydroxybenzoic acid) were investigated for their potential as chelating agents. Both phenolics are known to possess different binding sites that may play important roles in their chelating activity. 2-Aminophenol contains neighboring $\mathrm{N}$ and $\mathrm{O}$ donor atoms in the aromatic ring, which allow the compound to form stable fivemembered-ring complexes with metal ions [14]. The compound was also found to have antibacterial activity against gram-negative Bacillus $[15,16]$. Its administration into animals also showed no toxic effects and the compound was excreted in conjugation with both sulfuric acid and glucuronic acid [17]. Another potential chelator, 3,4-dihydroxybenzoic acid, was reported to have chemoprevention activity against carcinogenesis [18-20]. This compound 
was found to be effective in inhibiting colon, skin and liver cancers, either in the initiation phase or in the promotion/progression of carcinogenesis. It also shows antioxidant activity due to the occurrence of a carboxylic group and two adjacent hydroxyl groups. These functional groups may act as inhibitors of free radical reactions by forming complexes with transition metal ions $\mathrm{CCu}^{2+}$ and $\mathrm{Fe}^{2+}$ ) and thus may lower the activity of enzymes that catalyze the reactions of free radical formation [21,22].

In order to gain an initial understanding and basic information on metal chelation for further research in chelation therapy, this study investigated the complexation of 2-aminophenol and 3,4dihydroxybenzoic acid with divalent metal ions $\left(\mathrm{Mn}^{2+}, \mathrm{Co}^{2+}, \mathrm{Ni}^{2+}\right.$, $\mathrm{Cu}^{2+}, \mathrm{Zn}^{2+}$ and $\left.\mathrm{Be}^{2+}\right)$ in binary and ternary systems. While many stability constants of metal ions and 3,4-dihydroxybenzoic acid have been reported before, only very limited information can be found regarding the metal complexing abilities of the 2-aminophenol ligand. In addition, the usefulness of these chelating agents to reduce excess metal ions in ternary system with both ligands has never been investigated before. Therefore, it is necessary to understand the possible chelation processes and stable complexes formed between these chelators and certain metal ions. While most reported works were carried out at $25^{\circ} \mathrm{C}$ and with an ionic strength $0-0.2 \mathrm{~mol} \mathrm{dm}^{-3} \mathrm{NaCl}$, all the experimental studies in this work were carried out at physiological conditions which mimic body fluids $\left(37 \pm 0.1{ }^{\circ} \mathrm{C}\right.$ and $0.15 \mathrm{~mol} \mathrm{dm}^{-3} \mathrm{NaCl}$ ) to gain reliable results for further research in drug development for chelation therapy. The stability constant study helps to understand the interaction strength between the chelating agent and metal ion in forming complexes. The complexing abilities were investigated using a potentiometric method and the Hyperquad2008 program. The speciation model was determined using the HySS2009 program. UV-Vis spectrophotometry was performed to determine the first protonation constant of the 3,4-dihydroxybenzoic acid, to qualitatively verify the protonation of the ligands and to confirm the model of the complexes formed.

\section{Materials and methods}

\subsection{Materials}

The chemicals used in this study and their suppliers are as follows: 2-aminophenol ( $\mathrm{MW}=109.1 ; 0.99$ purity) and 3,4-dihydroxybenzoic acid (MW $=154.1,0.97$ purity), Alfa Aesar (Lancashire, UK); nickel chloride hexahydrate (MW = 237.7, 0.98 purity) and beryllium sulfate tetrahydrate ( $\mathrm{MW}=177.1,0.98$ purity), Alfa Aesar (Lancashire, UK); zinc nitrate hexahydrate (MW $=297.5,0.98$ purity) and manganese chloride tetrahydrate (MW = 197.9, 0.998 purity), Acros Organics (Morris Plains, NJ); cobalt nitrate hexahydrate (MW $=291.0,0.98$ purity), copper chloride dihydrate ( $\mathrm{MW}=170.5,0.99$ purity), potassium hydrogen phthalate (MW $=58.45,0.99$ purity), Sigma Aldrich (Steinheim, Germany); sodium hydroxide (MW = 40, 0.96 purity), Yakuri Pure Chemicals (Kyoto, Japan); sodium chloride (MW = 58.44, 0.995 purity), Showa (Tokyo, Japan); hydrochloric acid (MW $=63.01$, 0.376 purity), Fisher Scientific (Hampton, NH). All chemicals were directly used without further purification. Solutions were prepared daily in distilled deionized water (resistance $>18 \mathrm{M} \Omega$ ). In particular, solutions of metal salts, $\mathrm{NaOH}$ and $\mathrm{HCl}$ were standardized before used.

\subsection{Potentiometric measurement}

The following solutions, each with a total volume of $50 \mathrm{~cm}^{3}$, were prepared in a $100 \mathrm{~cm}^{3}$ double walled equilibrium cell for
pH-potentiometric measurements and each was titrated against standard carbonate-free $\mathrm{NaOH}\left(0.10 \mathrm{~mol} \mathrm{dm}^{-3}\right)$.

(a) $3 \times 10^{-3} \mathrm{~mol} \mathrm{dm}^{-3} \mathrm{HCl}+1.5 \times 10^{-1} \mathrm{~mol} \mathrm{dm}^{-3} \mathrm{NaCl}$.

(b) Solution $\mathrm{a}+1 \times 10^{-3} \mathrm{~mol} \mathrm{dm}^{-3}$ 2-aminophenol (A) or 3,4-dihydroxybenzoic acid (D).

(c) Solution a $+1 \times 10^{-3}-1.2 \times 10^{-3} \mathrm{~mol} \mathrm{dm}^{-3} \mathrm{~A} \quad$ or $\mathrm{D}+4 \times 10^{-4}-1 \times 10^{-3} \mathrm{~mol} \mathrm{dm}{ }^{-3}$ metal salt.

(d) Solution a $+5 \times 10^{-4}-1 \times 10^{-3} \mathrm{~mol} \mathrm{dm}^{-3} \quad \mathrm{~A}+4 \times 10^{-4}$ $-1 \times 10^{-3} \mathrm{~mol} \mathrm{dm}^{-3} \quad \mathrm{D}+4 \times 10^{-4}-1 \times 10^{-3} \mathrm{~mol} \mathrm{dm}^{-3}$ metal salt.

Prior to titration, each solution was kept at $37 \pm 0.1^{\circ} \mathrm{C}$ for 15 min by connecting the equilibrium cell to a refrigerated circulating bath equipped with a thermocouple to closely monitor the reaction temperature. During potentiometric measurements, the temperature and ionic strength of the system were maintained at a constant $37 \pm 0.1^{\circ} \mathrm{C}$ and $0.15 \mathrm{~mol} \mathrm{dm}^{-3} \mathrm{NaCl}$, respectively. At least three repetitions for the $\mathrm{pH}$-potentiometry procedure were carried out for each experiment, with a reproducibility of \pm 0.02 in $\mathrm{pH}$ units.

The potentiometric titrations were performed using a meterohm 888-Titrando Autotitrator equipped with a Dosimat model 805, 802 rod stirrer and $804 \mathrm{Ti}$ stand, and an Ecotrode Plus pH glass electrode was used for potentiometric measurements. The instrument was connected to a personal computer equipped with Tiamo 2.3 computer software to control the titration conditions and record the experimental data. The glass electrode response was able to give a $\mathrm{pH}$ reading with a precision of \pm 0.001 . Prior to use, the electrode was calibrated with standard buffer solutions ( $\mathrm{pH} 4.00,7.00$ and 10.00 ) at the same temperature used for the main experimental work $\left(37 \pm 0.1^{\circ} \mathrm{C}\right)$. Since the determination of metal-ligand stability constants was carried out at high ionic strength $\left(0.15 \mathrm{~mol} \mathrm{dm}^{-3} \mathrm{NaCl}\right)$, it was necessary to carry out a strong acid-strong base titration for the glass electrode calibration. For this purpose, the titration curve of solution a was processed using the Glass Electrode Evaluation (GLEE) program to evaluate the calibration of the glass electrode and to estimate carbonate contaminant for each investigation [23].

The titration curve of solution $b$ was later processed by the Hyperquad2008 program in order to determine the protonation constant of the ligands. In contrast, the investigations of metal ligand stability constants in the binary and ternary systems were carried out by processing the titration curves of solutions $c$ and $\mathrm{d}$, respectively. As shown in Table 1, the metal ligand complexation studies in the binary system were done at four different metalto-ligand ratios, while ternary studies were done at three different metal:ligand A:ligand D ratios, to cover all possible complex species that may occur in the system.

Table 1

Concentrations of metal and ligand in solution c that were used to determine the overall formation constants of binary complexes.

\begin{tabular}{llll}
\hline \multirow{2}{*}{ Ratios } & \multicolumn{2}{l}{ Concentration $\left(\mathrm{mol} \mathrm{dm}^{-3}\right)$} \\
\cline { 2 - 4 } & Metal & Ligand A & Ligand D \\
\hline Binary $[M]:[L]$ & $1.0 \times 10^{-3}$ & $1.0 \times 10^{-3}$ & \\
$1: 1$ & $5.0 \times 10^{-4}$ & $1.0 \times 10^{-3}$ & \\
$1: 2$ & $4.0 \times 10^{-4}$ & $1.0 \times 10^{-3}$ & \\
$1: 2.5$ & $4.0 \times 10^{-4}$ & $1.2 \times 10^{-3}$ & \\
$1: 3$ & & & $1.0 \times 10^{-3}$ \\
Ternary $[M]:[A]:[D]$ & $1.0 \times 10^{-3}$ & $5.0 \times 10^{-3}$ \\
$1: 1: 1$ & $1.0 \times 10^{-3}$ & $5.0 \times 10^{-4}$ & \\
$1: 1: 2$ & $5.0 \times 10^{-4}$ & $1.0 \times 10^{-3}$ & \\
$1: 2: 1$ & $5.0 \times 10^{-4}$ & &
\end{tabular}




\subsection{Software analysis}

Hyperquad2008 was used to determine the formation constants of the complex species formed in the system using a non-linear least-squares algorithm. Various models with possible compositions of complex species were proposed in the program and the one that gave the best fitted model was chosen [24,25]. The goodness of fitting was statistically presented as a sigma $(\sigma)$ value and was obtained from the following equation:

$\sigma=\sqrt{\frac{\left[\sum_{i=1, n p}\left(W_{i} r_{i}^{2}\right)\right]}{(m-n)}}$

where $W_{i}, r_{i}, m$ and $n$ refer to the weight at the $i$ th data point, the residual at the $i$ th data point, the number of titration data points and the refined parameters, respectively. In this study, the number

Table 2

Protonation constants ${ }^{\mathrm{a}}\left(\log K_{n}\right)$ of ligands A and D at $37 \pm 0.1^{\circ} \mathrm{C}, I=0.15 \mathrm{~mol} \mathrm{dm}^{-3}$ $\mathrm{NaCl}$

\begin{tabular}{lllll}
\hline Ligand & $\log K_{1} \pm \mathrm{SD}^{\mathrm{b}}$ & $\log K_{2} \pm \mathrm{SD}^{\mathrm{b}}$ & $\log K_{3} \pm \mathrm{SD}^{\mathrm{b}}$ & $\sigma$ \\
\hline $\mathrm{A}$ & $9.58 \pm 0.01$ & $4.53 \pm 0.01$ & & 1.22 \\
& $\left(9.87^{\mathrm{c}}\right)$ & $\left(4.74^{\mathrm{c}}\right)$ & & \\
$\mathrm{D}$ & $12.75 \pm 0.02$ & $8.62 \pm 0.01$ & $4.42 \pm 0.01$ & 1.17 \\
& $\left(12.80^{\mathrm{d}} ; 13.10^{\mathrm{e}}\right)$ & $\left(8.70^{\mathrm{d}} ; 8.67^{\mathrm{e}}\right)$ & $\left(4.50^{\mathrm{d}} ; 4.25^{\mathrm{e}}\right)$ & \\
\hline
\end{tabular}

a All measurements were carried out by potentiometric measurements and with the Hyperquad software, except for the $\log K_{1}$ value of ligand $\mathrm{D}$, which was investigated by UV-Vis spectrophotometry measurements and the HySpec software.

b Standard deviation value of the last decimal place; $\pm 95 \%$ confidence interval.

c Ref. [33], $T=25^{\circ} \mathrm{C} ; I=0.1 \mathrm{~mol} \mathrm{dm}{ }^{-3} \mathrm{KCl}$.

d Ref. [30], $T=25^{\circ} \mathrm{C} ; I=0.02 \mathrm{~mol} \mathrm{dm}^{-3} \mathrm{KNO}_{3}$.

e Ref. [35], $T=25^{\circ} \mathrm{C} ; I=0.2 \mathrm{~mol} \mathrm{dm}{ }^{-3} \mathrm{KCl}$. of points used for each refinement was between 80 and 200 points. The residual at the $i$ th data point is defined as the difference between the observed and the calculated $\mathrm{pH}$ values. The fitting model is considered to be good if the sigma $(\sigma)$ value is in the range $1.17-1.35$. It specifically represents $95 \%$ goodness of fitting [24].

The result of refinement is generally expressed as the overall formation constant $\left(\beta_{\text {pqrs }}\right)$ which is described in Eq. (2):

$p \mathrm{M}+q \mathrm{~A}+r \mathrm{D}+s \mathrm{H} \leftrightarrow \mathrm{M}_{p} \mathrm{~A}_{q} \mathrm{D}_{r} \mathrm{H}_{s} \quad \beta_{p q r s}=\frac{\left[\mathrm{M}_{p} \mathrm{~A}_{q} \mathrm{D}_{r} \mathrm{H}_{s}\right]}{[\mathrm{M}]^{p}[\mathrm{~A}]^{q}[\mathrm{D}]^{r}[\mathrm{H}]^{s}}$

where the variables $p, q, r$ and $s$ represent the stoichiometric coefficients of the metal ions (M), 2-aminophenol (A), 3,4-dihydroxybenzoic acid (D) and hydrogen ions (H), respectively. A higher value of this constant indicates greater stability of the complex $[26,27]$. All standard deviations are provided directly from refinement of the Hyperquad software. In order to support the result from the Hyperquad2008 program, HySS2009 was used to simulate and illustrate the possible species distribution of ligand protonation and metal-ligand complex at different $\mathrm{pH}$ values [28].

\subsection{UV-Vis spectrophotometric measurement}

All spectrophotometric measurements were carried out in standard $1 \mathrm{~cm}$ quartz cells at $200-800 \mathrm{~nm}$ by using a JASCO V-550 spectrophotometer. Prior to the measurements, the following solutions were prepared with a total volume of $50 \mathrm{~cm}^{3}$ :

(i) $1.5 \times 10^{-1} \mathrm{~mol} \mathrm{dm}^{-3} \mathrm{NaCl}+2 \times 10^{-4} \mathrm{~mol} \mathrm{dm}^{-3}$ ligand $\mathrm{D}$.

(ii) $1.5 \times 10^{-1} \mathrm{~mol} \mathrm{dm}^{-3} \mathrm{NaCl}+2 \times 10^{-4} \mathrm{~mol} \mathrm{dm}^{-3}$ ligand $\mathrm{A}$ or $\mathrm{D}+1 \times 10^{-4} \mathrm{~mol} \mathrm{dm}^{-3}$ metal salt.

(iii) $1.5 \times 10^{-1} \mathrm{~mol} \mathrm{dm}^{-3} \mathrm{NaCl}+2 \times 10^{-4} \mathrm{~mol} \mathrm{dm}^{-3} \quad$ ligand $\mathrm{D}+2 \times 10^{-4} \mathrm{~mol} \mathrm{dm}^{-3}$ metal salt. (a)

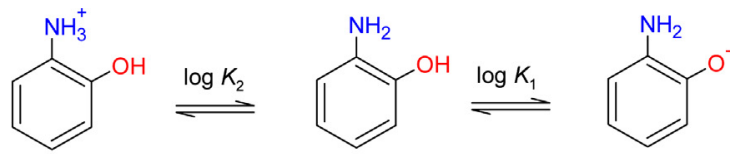

(b)

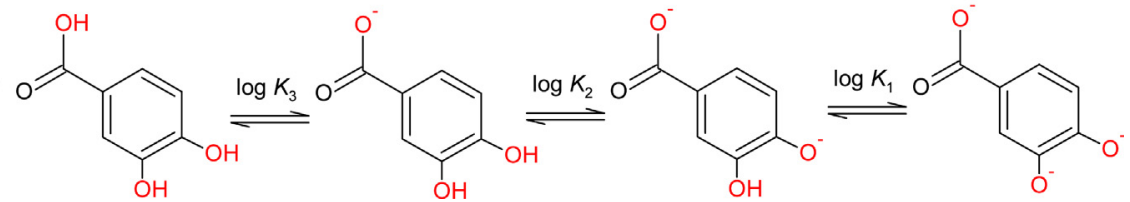

Fig. 1. Protonation equilibria for: (a) 2-aminophenol (A); and (b) 3,4-dihydroxybenzoic acid (D).
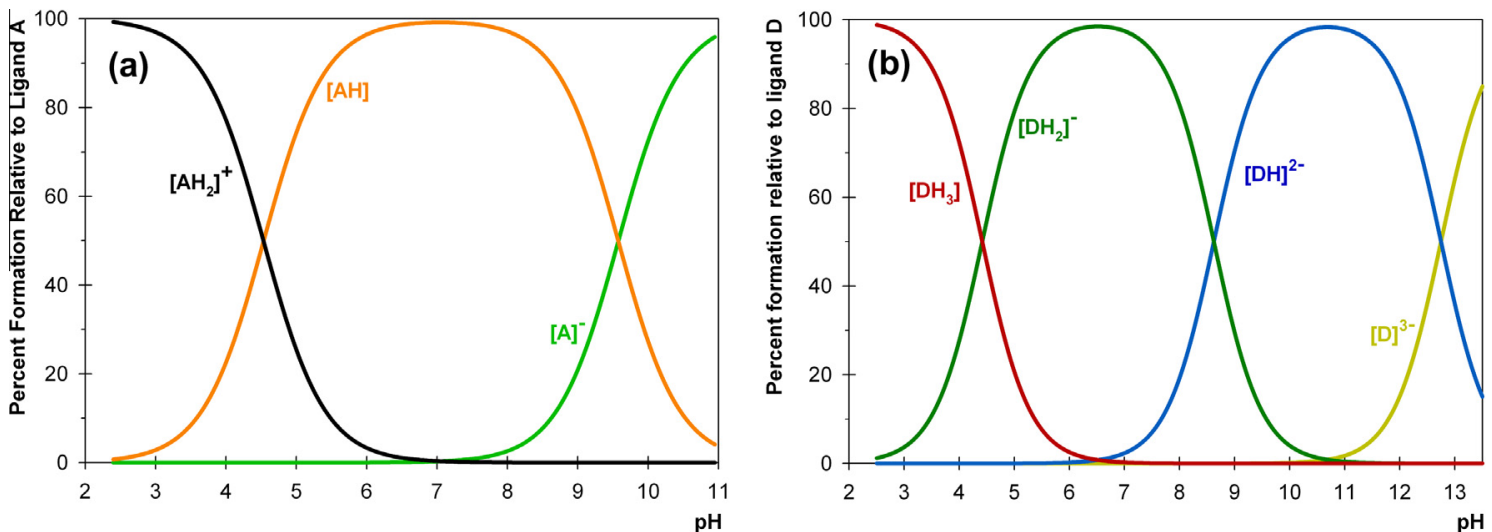

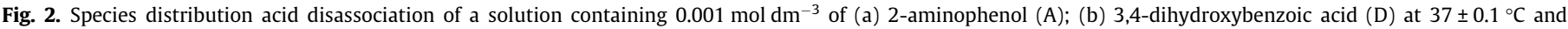
$I=0.15 \mathrm{~mol} \mathrm{dm}^{-3} \mathrm{NaCl}$ 
(iv) $5 \times 10^{-2} \mathrm{~mol} \mathrm{dm}^{-3}$ ligand $\mathrm{A}+5 \times 10^{-2} \mathrm{~mol} \mathrm{dm}^{-3}$ ligand $\mathrm{D}+5 \times 10^{-2} \mathrm{~mol} \mathrm{dm}^{-3}$ metal salt.

The temperatures of these solutions were maintained at $37 \pm 0.1^{\circ} \mathrm{C}$. The spectra of solution (i) between $\mathrm{pH} 2.5$ and 13.5 were used to determine the protonation constant of ligand D. While solutions (ii) and (iii) were used to determine the stability constants of the complexes in the binary and ternary systems, respectively. The values will be used later to support the stability constants obtained from potentiometric measurements. The UVVis spectra of solutions (i)-(iii) at pH 2.5 to 11.0 then were processed in the Hypspec2006 program to refine the constants [28]. Further confirmation of the $d-d$ block transition spectrum of the complexes was performed on the ternary system. For this purpose, the spectra of solution (iv) were scanned at pH 2.5 and 11.0. Three repetitions were done for each measurement and each system was maintained with conditions similar to that used in the potentiometric titration. $\mathrm{NaOH}$ was used to adjust the system $\mathrm{pH}$ to the desired value.

\section{Results and discussion}

\subsection{Protonation constants}

Protonation constants are used in metal chelation studies to predict at which pH the ligand is ionized and able to form complexes with metal ions. In this work, the protonation of 2-aminophenol (ligand A) and 3,4-dihydroxybenzoic acid (ligand D) was studied by using a potentiometric titration method and their protonation constants, expressed as stepwise association constants $(\log K)$, were determined using the Hyperquad2008 program. As presented in Table 2, the $\log K$ values of ligands $\mathrm{A}$ and $\mathrm{D}$ obtained in this study are comparable to those reported in the literature, after taking into consideration the differences in experimental conditions [29,30].

Ligand A possesses two functional groups, the first protonation occurred at $\log K=9.58$, followed by a second protonation at $\log K=4.53$. The amino group $\left(-\mathrm{NH}_{2}\right)$ is known to be more acidic than the phenol group $(-\mathrm{OH})$, thus it was suggested that the first
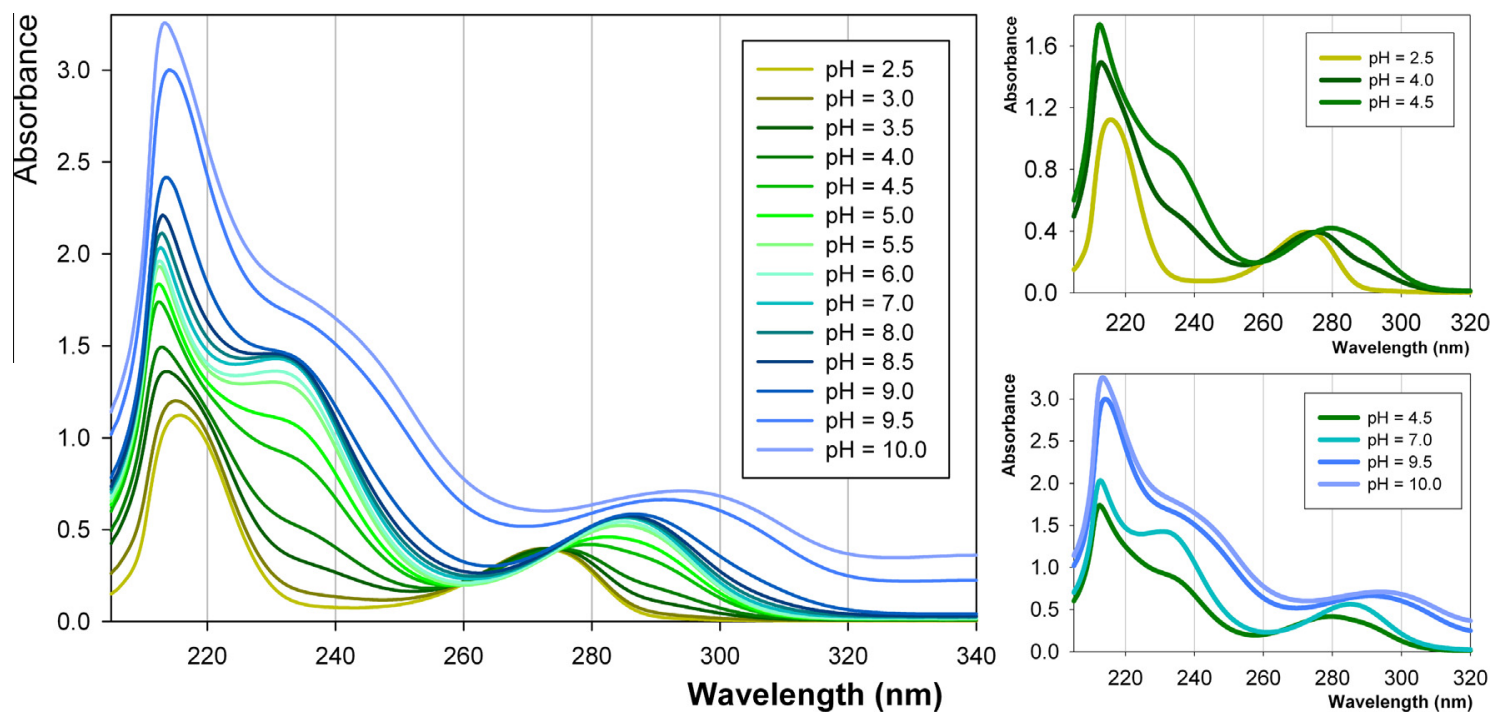

Fig. 3. UV-Vis spectra of 2 -aminophenol $(\mathrm{A})$, where $[A]=0.001 \mathrm{~mol} \mathrm{dm}^{-3}, T=37 \pm 0.1{ }^{\circ} \mathrm{C}, I=0.15 \mathrm{~mol} \mathrm{dm}^{-3} \mathrm{NaCl}$.
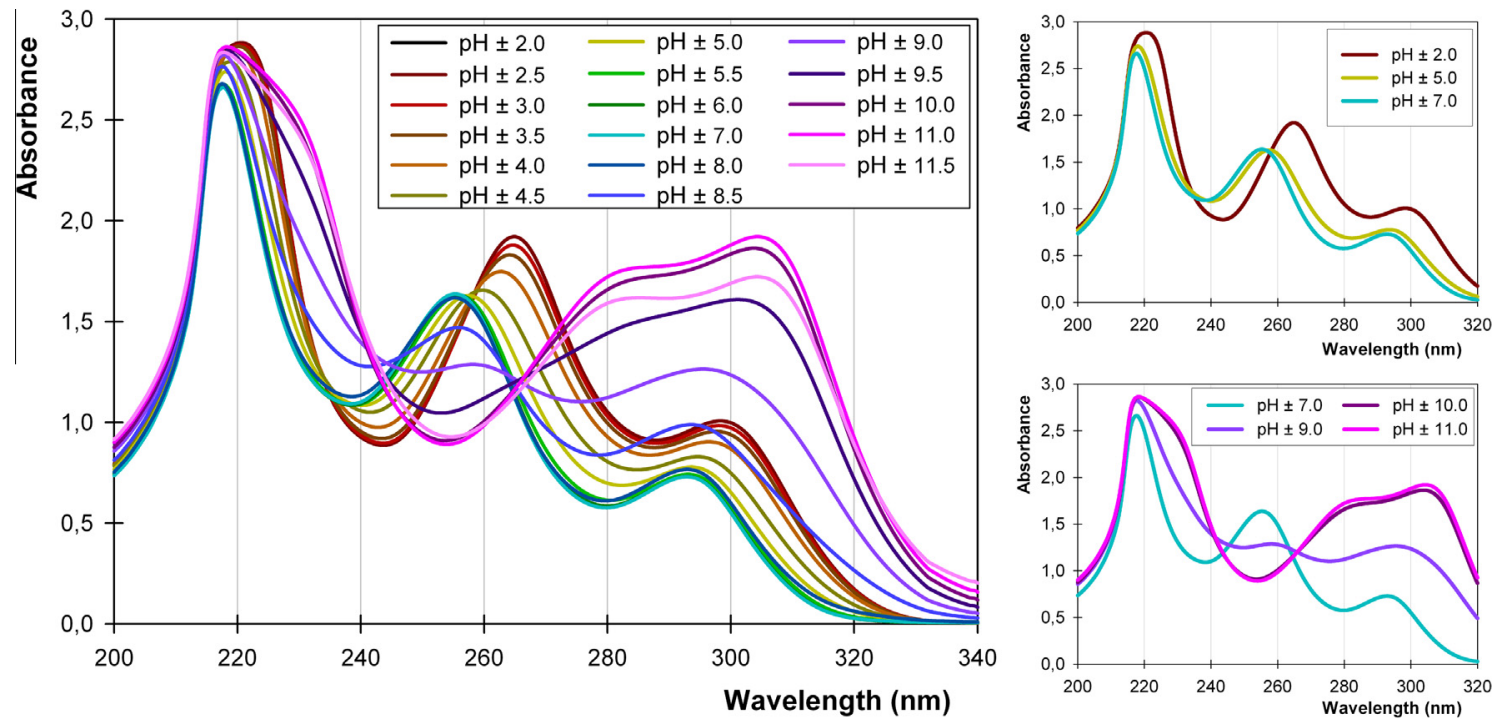

Fig. 4. UV-Vis spectra of 3,4-dihydroxybenzoic acid (D), where $[D]=0.001 \mathrm{~mol} \mathrm{dm}^{-3}, T=37 \pm 0.1^{\circ} \mathrm{C}, I=0.15 \mathrm{~mol} \mathrm{dm}{ }^{-3} \mathrm{NaCl}$. 

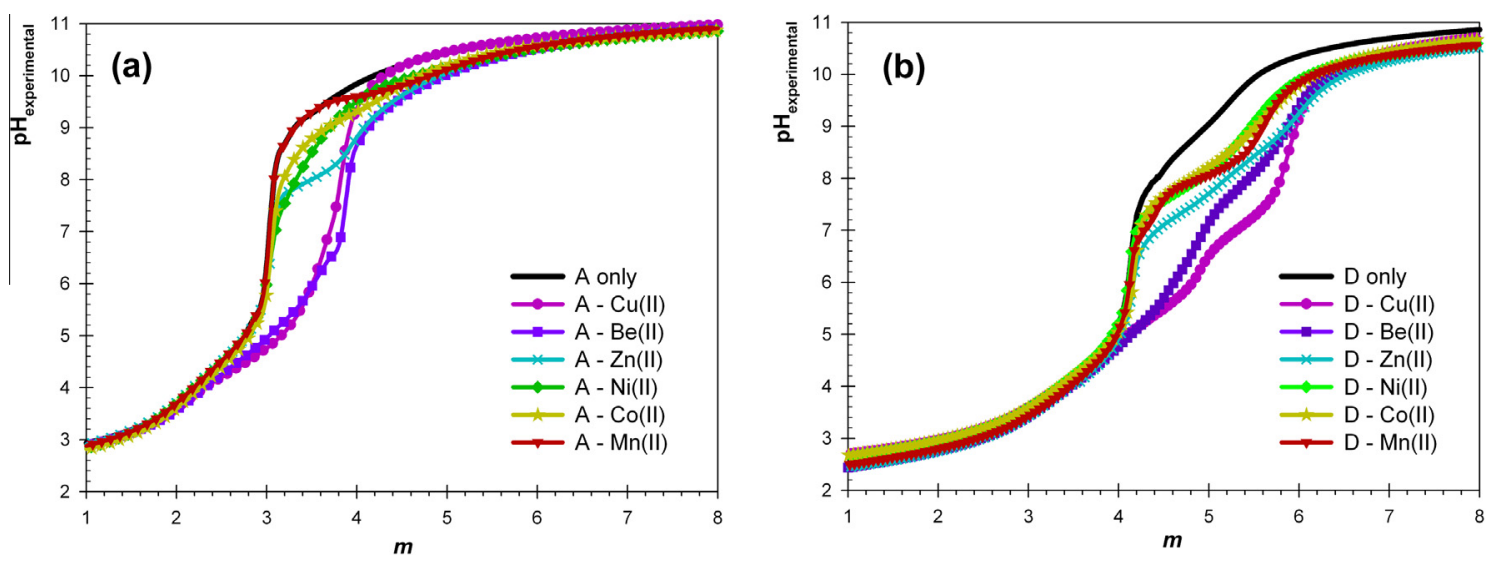

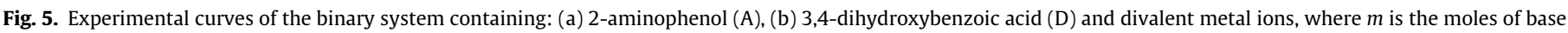
added per mole of ligand.

Table 3

Logarithms of overall stability constants of 2-aminophenol (A) with several metals $\left(\log \beta_{p q s}\right)$ at $37 \pm 0.1^{\circ} \mathrm{C}, I=0.15 \mathrm{~mol} \mathrm{dm}^{-3} \mathrm{NaCl}$.

\begin{tabular}{|c|c|c|c|c|c|c|}
\hline \multirow[t]{2}{*}{ Complex species } & \multirow[t]{2}{*}{$p$} & \multirow[t]{2}{*}{$q$} & \multirow[t]{2}{*}{$s$} & \multicolumn{2}{|c|}{$\log \beta_{\mathrm{pqs}^{\mathrm{a}}} \pm \mathrm{SD}^{\mathrm{b}}$} & \multirow[t]{2}{*}{ Ref. } \\
\hline & & & & Hyperquad & Hypspec & \\
\hline $\begin{array}{l}\mathrm{M}=\mathrm{Cu}^{2+} \\
{[\mathrm{MAH}]^{2+}} \\
{[\mathrm{MA}]^{+}} \\
{\left[\mathrm{MA}_{2}\right]} \\
(\sigma=1.22)^{\mathrm{d}}\end{array}$ & $\begin{array}{l}1 \\
1 \\
1\end{array}$ & $\begin{array}{l}1 \\
1 \\
2\end{array}$ & $\begin{array}{l}1 \\
0 \\
0\end{array}$ & $\begin{array}{l}12.61 \pm 0.04 \\
8.48 \pm 0.01 \\
14.84 \pm 0.04\end{array}$ & $\begin{array}{l}- \\
8.61 \pm 0.01 \\
14.94 \pm 0.08\end{array}$ & $\begin{array}{l}- \\
8.36^{c} \\
-\end{array}$ \\
\hline $\begin{array}{l}\mathrm{M}=\mathrm{Be}^{2+} \\
{[\mathrm{MAH}]^{2+}} \\
{[\mathrm{MA}]^{+}} \\
{\left[\mathrm{MA}_{2}\right]} \\
{\left[\mathrm{MA}_{3}\right]^{-}} \\
(\sigma=1.29)^{\mathrm{d}}\end{array}$ & $\begin{array}{l}1 \\
1 \\
1 \\
1\end{array}$ & $\begin{array}{l}1 \\
1 \\
2 \\
3\end{array}$ & $\begin{array}{l}1 \\
0 \\
0 \\
0\end{array}$ & $\begin{array}{l}13.08 \pm 0.02 \\
8.12 \pm 0.01 \\
14.86 \pm 0.03 \\
19.62 \pm 0.06\end{array}$ & $\begin{array}{l}14.03 \pm 0.03 \\
8.04 \pm 0.03 \\
14.47 \pm 0.08 \\
-\end{array}$ & $\begin{array}{l}- \\
- \\
-\end{array}$ \\
\hline $\begin{array}{l}M=\mathrm{Zn}^{2+} \\
{\left[\mathrm{MA}^{+}\right.} \\
{\left[\mathrm{MA}_{2}\right]} \\
(\sigma=1.33)^{\mathrm{d}}\end{array}$ & $\begin{array}{l}1 \\
1\end{array}$ & $\begin{array}{l}1 \\
2\end{array}$ & $\begin{array}{l}0 \\
0\end{array}$ & $\begin{array}{l}5.26 \pm 0.01 \\
9.72 \pm 0.04\end{array}$ & $\begin{array}{l}5.18 \pm 0.02 \\
10.07 \pm 0.08\end{array}$ & $\begin{array}{l}- \\
-\end{array}$ \\
\hline $\begin{array}{l}\mathrm{M}=\mathrm{Ni}^{2+} \\
{[\mathrm{MA}]^{+}} \\
{\left[\mathrm{MA}_{2}\right]} \\
(\sigma=1.26)^{\mathrm{d}}\end{array}$ & $\begin{array}{l}1 \\
1\end{array}$ & $\begin{array}{l}1 \\
2\end{array}$ & $\begin{array}{l}0 \\
0\end{array}$ & $\begin{array}{l}4.74 \pm 0.01 \\
8.57 \pm 0.02\end{array}$ & $\begin{array}{l}4.76 \pm 0.02 \\
8.66 \pm 0.03\end{array}$ & $\begin{array}{l}- \\
-\end{array}$ \\
\hline $\begin{array}{l}\mathrm{M}=\mathrm{Co}^{2+} \\
{[\mathrm{MA}]^{+}} \\
{\left[\mathrm{MA}_{2}\right]} \\
(\sigma=1.33)^{\mathrm{d}}\end{array}$ & $\begin{array}{l}1 \\
1\end{array}$ & $\begin{array}{l}1 \\
2\end{array}$ & $\begin{array}{l}0 \\
0\end{array}$ & $\begin{array}{l}4.08 \pm 0.02 \\
7.63 \pm 0.03\end{array}$ & $\begin{array}{l}4.27 \pm 0.03 \\
7.96 \pm 0.04\end{array}$ & - \\
\hline $\begin{array}{l}\mathrm{M}=\mathrm{Mn}^{2+} \\
{[\mathrm{MA}]^{+}} \\
{\left[\mathrm{MA}_{2}\right]} \\
(\sigma=1.30)^{\mathrm{d}}\end{array}$ & $\begin{array}{l}1 \\
1\end{array}$ & $\begin{array}{l}1 \\
2\end{array}$ & $\begin{array}{l}0 \\
0\end{array}$ & $\begin{array}{l}3.52 \pm 0.11 \\
6.64 \pm 0.07\end{array}$ & $\begin{array}{l}3.36 \pm 0.05 \\
6.91 \pm 0.04\end{array}$ & - \\
\hline
\end{tabular}

a $p, q$, and $s$ represent the stoichiometric coefficients of the metal ions, 2-aminophenol (A) and the proton of the ligand, respectively.

b Standard deviation value of the last decimal place; $\pm 95 \%$ confidence interval.

c Ref. [35], $T=25^{\circ} \mathrm{C} ; I=0.2 \mathrm{~mol} \mathrm{dm}^{-3} \mathrm{NaClO}_{4}$.

d The sigma $(\sigma)$ value expresses the goodness of potentiometric data fitting using Hyperquad2008.

protonation of ligand A occurred at its phenol site [31]. While for ligand D, due to its vicinal diol and carboxylic functional groups, this ligand has been shown to have three protonation constants $\left(\log K_{1}=12.75, \log K_{2}=8.62\right.$ and $\left.\log K_{3}=4.42\right)$. Deprotonation of ligand $\mathrm{D}$ starts at its carboxyl group, followed by second and third acid deprotonations at its less acidic para and meta hydroxyl groups, respectively [32]. The hydroxyl substitute in the para position is much easier to deprotonate due to a resonance effect [33]. This effect is particularly influenced by the occurrence of the negative-charged carboxylic group, which results in electron delocal-
Table 4

Logarithms of overall stability constants of 3,4-dihydroxybenzoic acid (D) with several metals $\left(\log \beta_{\text {prs }}\right)$ at $37 \pm 0.1{ }^{\circ} \mathrm{C}, I=0.15 \mathrm{~mol} \mathrm{dm}^{-3} \mathrm{NaCl}$.

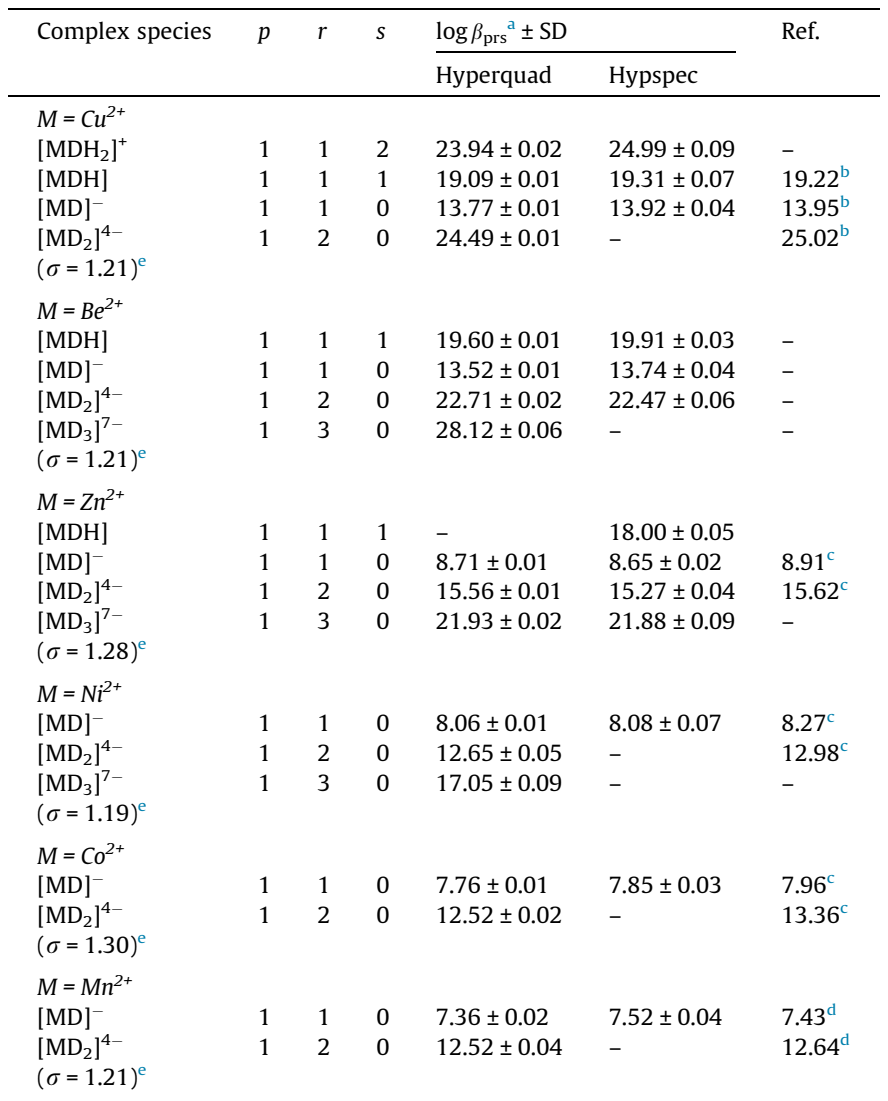

${ }^{a} p, q$, and $s$ represent the stoichiometric coefficients of the metal ions, 3,4dihydroxybenzoic acid (D) and the proton of the ligand, respectively.

b Ref. [35], $T=25^{\circ} \mathrm{C} ; I=0.2 \mathrm{~mol} \mathrm{dm}^{-3} \mathrm{KCl}$.

c Ref. [35], $T=30^{\circ} \mathrm{C} ; \mathrm{I}=0.1 \mathrm{~mol} \mathrm{dm}{ }^{-3} \mathrm{KNO}_{3}$.

d Ref. [35], $T=25^{\circ} \mathrm{C} ; I=1.0 \mathrm{~mol} \mathrm{dm}^{-3} \mathrm{NaClO}_{4}$.

e The sigma $(\sigma)$ value expresses the goodness of potentiometric data fitting using Hyperquad2008.

ization along the benzene ring. The system then tends to lose one proton of the para-hydroxyl group and rearrange the electron distribution [34]. According to these descriptions, the protonation equilibria of the ligands A and D are depicted in Fig. 1(a) and (b), respectively. 

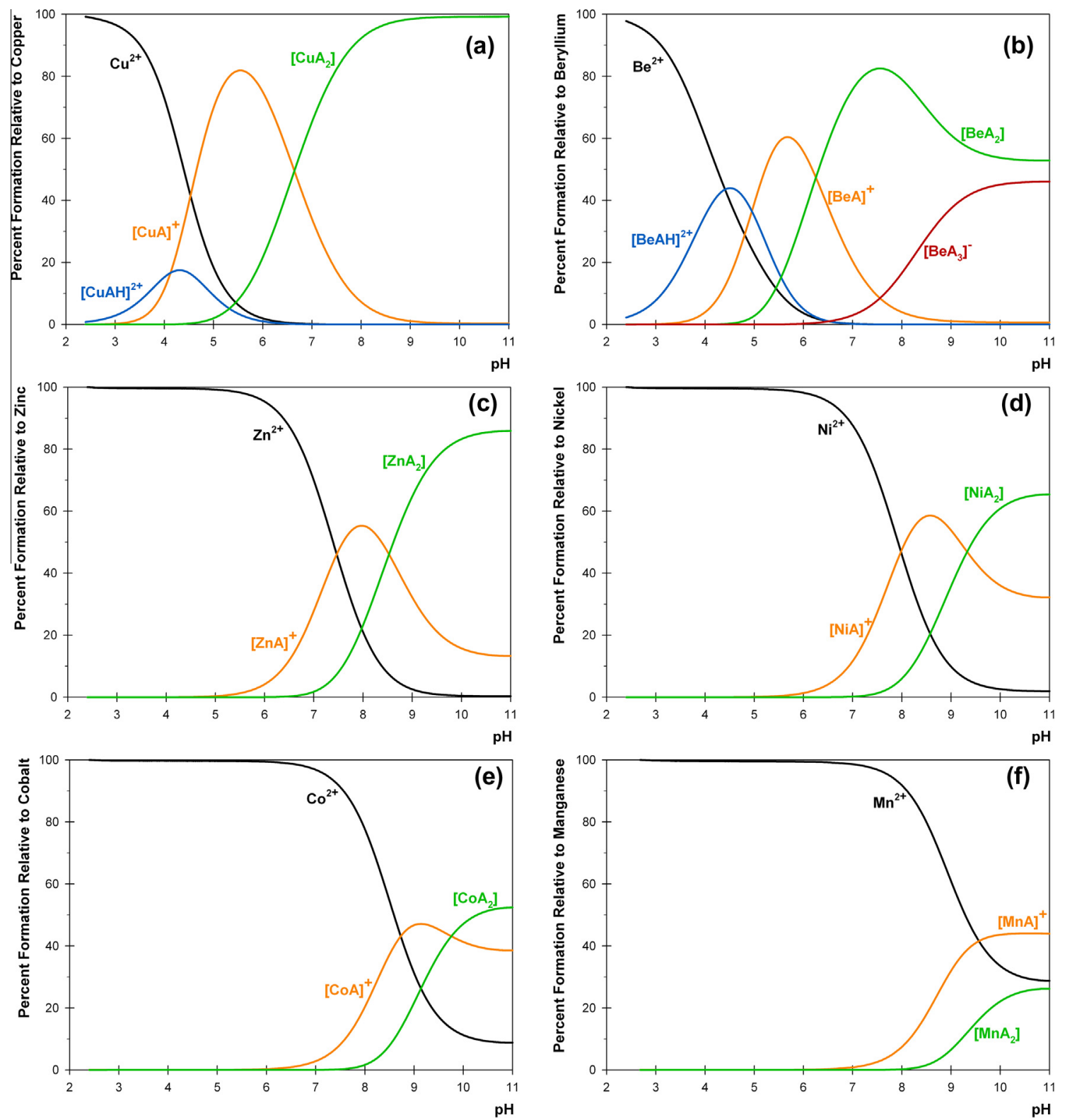

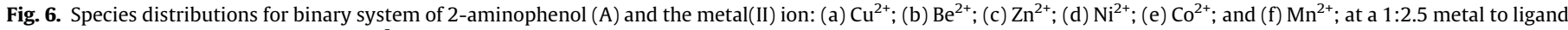
ratio, $T=37 \pm 0.1{ }^{\circ} \mathrm{C}$ and $I=0.15 \mathrm{~mol} \mathrm{dm}^{-3} \mathrm{NaCl}$.

The obtained protonation constants were then introduced into the HySS2009 program to obtain the speciation diagrams of the deprotonated ligands (Fig. 2). These species distribution diagrams will be used to explain the occurrence of shifting on the UV-Vis spectra obtained for the qualitative investigation of ligand protonation. As presented in Fig. 3, ligand A has two optimum peaks (216 and $272 \mathrm{~nm}$ ) at $\mathrm{pH} 2.5$. As the $\mathrm{pH}$ of the solution was increased to 4.0 , these peaks shifted to 213 and $278 \mathrm{~nm}$, followed by the appearance of shoulder peaks at increasing wavelengths. Assessed by the species diagram in Fig. 2(a), these shifts are likely to be caused by the ionization of $\left[\mathrm{AH}_{2}\right]^{+}$species, which started to deprotonate, and $22.60 \%$ were converted into [AH] species. With increasing $\mathrm{pH}$, more $[\mathrm{AH}]$ species were formed in the system (approximately $48.0 \%$ at $\mathrm{pH} 4.5$ ) and a larger bathochromic shift to 226 and $282 \mathrm{~nm}$ can be observed in its spectra. Both peak heights kept increasing until $\mathrm{pH} 7.0$, when $92.23 \%$ of ligand $\mathrm{A}$ appeared as $[\mathrm{AH}]$ species. At $\mathrm{pH} 9.5$, about $45 \%$ of this ligand lost its second proton to form $[\mathrm{A}]^{-}$species, thus its maximum peaks shifted to 214 and $291 \mathrm{~nm}$.
UV-Vis spectra showing the shifts for the ligand $\mathrm{D}$ between $\mathrm{pH}$ 2.5 and 10.0 are presented in Fig. 4. At pH 2, three distinct optimum peaks at 221, 265 and $298 \mathrm{~nm}$ can be observed. These peaks are hypsochromically shifted to 218, 256 and $293 \mathrm{~nm}$, respectively, as the $\mathrm{pH}$ is increased to about 5. Compared to the species that are formed at this $\mathrm{pH}$ (Fig. 2(b)), it is suggested that the alteration is caused by the presence of $79.24 \%$ of ligand $\mathrm{D}$ which has lost one proton and formed $\left[\mathrm{DH}_{2}\right]^{-}$species. When the $\mathrm{pH}$ is increased to 7.0, most species (97.42\%) appear as $\left[\mathrm{DH}_{2}\right]^{-}$, thus no change of the maximum wavelengths was found, instead an increase of the absorbance can be noticed. Another significant spectral change of ligand $\mathrm{D}$ can be observed at $\mathrm{pH} 9$, where $70 \%$ of the ligand in the solution exists in its monobasic form $[\mathrm{DH}]^{2-}$. At this $\mathrm{pH}$, the spectra showed the disappearance of peak at $256 \mathrm{~nm}$ that previously occurred at pH 5.0. A new third peak at $301 \mathrm{~nm}$ also shows a red shift and has higher intensity. $[\mathrm{DH}]^{2-}$ is predominant in the system at $\mathrm{pH} 10.0$ and a new second peak occurred at $288 \mathrm{~nm}$. In addition, its first peak has a broader shoulder, whereas its third peak has higher intensity. 

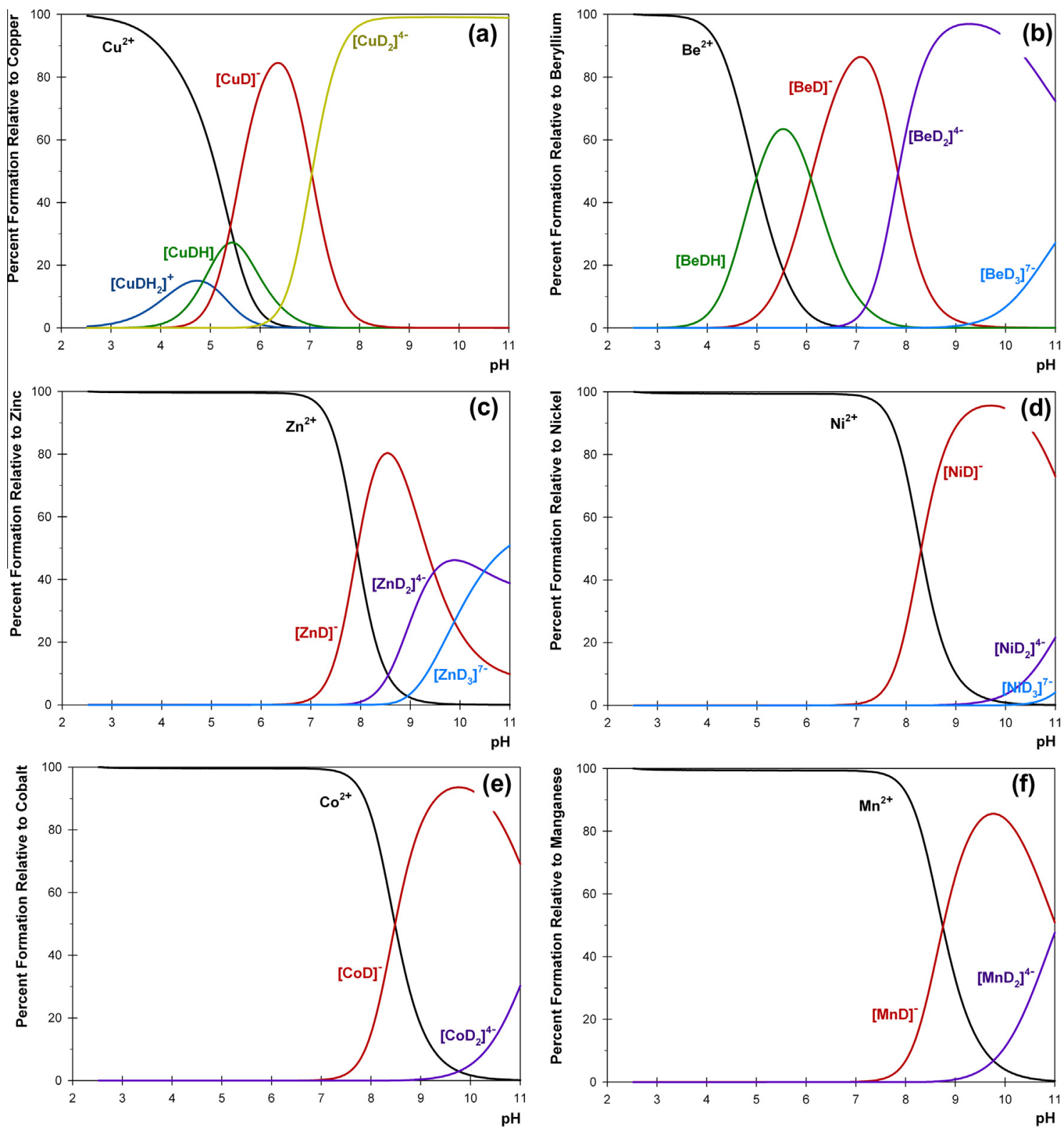

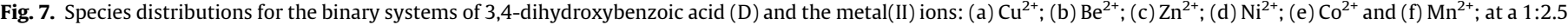
metal to ligand ratio, $T=37 \pm 0.1{ }^{\circ} \mathrm{C}$ and $I=0.15 \mathrm{~mol} \mathrm{dm}^{-3} \mathrm{NaCl}$.

\subsection{Binary system of metal-ligand complexes}

Several metal ions, where their atomic number increases following the trend: $\mathrm{Be}^{2+}<\mathrm{Mn}^{2+}<\mathrm{Co}^{2+}<\mathrm{Ni}^{2+}<\mathrm{Cu}^{2+}<\mathrm{Zn}^{2+}$, were used in this study. For the determination of the metal complex formation constant $(\log \beta)$ of the binary system, solution $c$, that consists of metal ions and ligand $A$ or $D$ in various molar ratios $(1: 1$, $1: 2,1: 2.5$ and $1: 3$ ) was titrated against carbonate free $\mathrm{NaOH}$ solution. Typical titration curves at a 1:2.5 metal to ligand ratio are shown in Fig. 5. For both ligands, it can be observed that there is a shifting of the buffer region to lower $\mathrm{pH}$ when metal ions are introduced into the system. The largest shifting occurred in the system containing $\mathrm{Cu}^{2+}$, followed by systems containing $\mathrm{Be}^{2+}$, $\mathrm{Zn}^{2+}, \mathrm{Ni}^{2+}, \mathrm{Co}^{2+}$ and $\mathrm{Mn}^{2+}$. This shifting suggests that the formation of the metal-ligand complex begins as the ligand starts to deprotonate.

Several combinations of complex species that may have occurred during the complexation reaction were introduced into the Hyperquad2008 program and the one that best fitted the experimental titration data was chosen. The results obtained from the refinement were expressed as overall formation constants $\left(\log \beta_{\mathrm{MpAqHs}}\right.$ or $\left.\log \beta_{\mathrm{MpDrHs}}\right)$ and are summarized in Tables 3 and 4 for the systems with ligands $A$ and $D$, respectively. In the binary system of the ligand $\mathrm{A}, \mathrm{Cu}^{2+}$ appears to have the highest stability $\left(\log \beta_{\text {CuA }}=8.48 \pm 0.01\right)$. The stability constants for the metals in the binary system follow the order: $\mathrm{Cu}^{2+}>\mathrm{Be}^{2+}>\mathrm{Zn}^{2+}>\mathrm{Ni}^{2+}>\mathrm{Co}^{2+}>\mathrm{Mn}^{2+}$.

For the binary complexes of ligand A with metal ions, most cases showed that the maximum numbers of substituents attached to the metal ion $\left(\left[\mathrm{MA}_{2}\right]\right)$ is two. The presence of $\left[\mathrm{MA}_{3}\right]^{-}$occurred only in the system with $\mathrm{Be}^{2+}$, which is due to the physical properties of this metal ion. $\mathrm{Be}^{2+}$ is known as a hard acid and has great coordination with hard bases, such as $\mathrm{R}-\mathrm{OH}$ and $\mathrm{R}-\mathrm{NH}_{2}$ that are part of the ligand $\mathrm{A}$ [36]. In addition, $\mathrm{Be}^{2+}$ has the smallest ionic radius among all metal ions used in this study [37]. Its size allows other ligands that still have a lone electron to approach close 
Table 5

Logarithms of the overall stability constants of ternary systems involving several metals $\left(\log \beta_{\text {pqrs }}\right)$ at $37 \pm 0.1^{\circ} \mathrm{C}$ and $I=0.15 \mathrm{~mol} \mathrm{dm}^{-3} \mathrm{NaCl}$.

\begin{tabular}{|c|c|c|c|c|c|c|}
\hline \multirow[t]{2}{*}{ Complex species } & \multirow[t]{2}{*}{$p$} & \multirow[t]{2}{*}{$q$} & \multirow[t]{2}{*}{$r$} & \multirow[t]{2}{*}{$s$} & \multicolumn{2}{|c|}{$\log \beta_{\mathrm{pqrs}}{ }^{\mathrm{a}, \mathrm{b}} \pm \mathrm{SD}^{\mathrm{c}}$} \\
\hline & & & & & Hyperquad & Hypspec \\
\hline $\begin{array}{l}\mathrm{M}=\mathrm{Cu}^{2+} \\
{[\mathrm{MADH}]^{-}} \\
{[\mathrm{MAD}]^{2-}} \\
(\sigma=1.19)^{\mathrm{d}}\end{array}$ & $\begin{array}{l}1 \\
1\end{array}$ & $\begin{array}{l}1 \\
1\end{array}$ & $\begin{array}{l}1 \\
1\end{array}$ & $\begin{array}{l}1 \\
0\end{array}$ & $\begin{array}{l}26.27 \pm 0.05 \\
19.58 \pm 0.03\end{array}$ & $\begin{array}{l}28.24 \pm 0.05 \\
20.65 \pm 0.07\end{array}$ \\
\hline $\begin{array}{l}M=B e^{2+} \\
{[\mathrm{MADH}]^{-}} \\
{[\mathrm{MAD}]^{2-}} \\
(\sigma=1.23)^{\mathrm{d}}\end{array}$ & $\begin{array}{l}1 \\
1\end{array}$ & $\begin{array}{l}1 \\
1\end{array}$ & $\begin{array}{l}1 \\
1\end{array}$ & $\begin{array}{l}1 \\
0\end{array}$ & $\begin{array}{l}27.20 \pm 0.02 \\
19.12 \pm 0.03\end{array}$ & $\begin{array}{l}27.23 \pm 0.02 \\
19.12 \pm 0.04\end{array}$ \\
\hline $\begin{array}{l}\mathrm{M}=\mathrm{Zn}^{2+} \\
{[\mathrm{MADH}]^{-}} \\
{[\mathrm{MAD}]^{2-}} \\
(\sigma=1.23)^{\mathrm{d}}\end{array}$ & $\begin{array}{l}1 \\
1\end{array}$ & $\begin{array}{l}1 \\
1\end{array}$ & $\begin{array}{l}1 \\
1\end{array}$ & $\begin{array}{l}1 \\
0\end{array}$ & $\begin{array}{l}22.44 \pm 0.04 \\
14.29 \pm 0.02\end{array}$ & $\begin{array}{l}25.22 \pm 0.04 \\
14.96 \pm 0.06\end{array}$ \\
\hline $\begin{array}{l}\mathrm{M}=\mathrm{Ni}^{2+} \\
{[\mathrm{MADH}]^{-}} \\
{[\mathrm{MAD}]^{2-}} \\
(\sigma=1.21)^{\mathrm{d}}\end{array}$ & $\begin{array}{l}1 \\
1\end{array}$ & $\begin{array}{l}1 \\
1\end{array}$ & $\begin{array}{l}1 \\
1\end{array}$ & $\begin{array}{l}1 \\
0\end{array}$ & $\begin{array}{l}22.20 \pm 0.02 \\
13.17 \pm 0.02\end{array}$ & $\begin{array}{l}22.96 \pm 0.03 \\
13.70 \pm 0.03\end{array}$ \\
\hline $\begin{array}{l}\mathrm{M}=\mathrm{Co}^{2+} \\
{[\mathrm{MADH}]^{-}} \\
{[\mathrm{MAD}]^{2-}} \\
(\sigma=1.15)^{\mathrm{d}}\end{array}$ & $\begin{array}{l}1 \\
1\end{array}$ & $\begin{array}{l}1 \\
1\end{array}$ & $\begin{array}{l}1 \\
1\end{array}$ & $\begin{array}{l}1 \\
0\end{array}$ & $\begin{array}{l}21.61 \pm 0.01 \\
13.11 \pm 0.01\end{array}$ & $\begin{array}{l}20.99 \pm 0.05 \\
13.26 \pm 0.03\end{array}$ \\
\hline $\begin{array}{l}\mathrm{M}=\mathrm{Mn}^{2+} \\
{[\mathrm{MADH}]^{-}} \\
{[\mathrm{MAD}]^{2-}} \\
(\sigma=1.19)^{\mathrm{d}}\end{array}$ & $\begin{array}{l}1 \\
1\end{array}$ & $\begin{array}{l}1 \\
1\end{array}$ & $\begin{array}{l}1 \\
1\end{array}$ & $\begin{array}{l}1 \\
0\end{array}$ & $\begin{array}{l}21.00 \pm 0.02 \\
11.56 \pm 0.03\end{array}$ & $\begin{array}{l}- \\
11.96 \pm 0.03\end{array}$ \\
\hline
\end{tabular}

${ }^{\text {a }} p, q, r$ and $s$ represent the stoichiometric coefficients of the metal ion, 2-aminophenol (A), 3,4-dihydroxybenzoic acid (A) and proton ion, respectively.

$\mathrm{b}$ No references were found for these complexes.

c Standard deviation value of the last decimal place; $\pm 95 \%$ confidence interval.

d The sigma $(\sigma)$ value expresses the goodness of potentiometric data fitting using Hyperquad2008.

enough to cause a strong ionic interaction. This interaction follows Coulomb's Law, where the force of attraction increases as the attracting species gets closer [38].

According to its speciation diagram (Fig. 6), the system with $\mathrm{Cu}^{2+}$ was able to form $[\mathrm{CuA}]^{+}$species in more acidic $\mathrm{pH}(\mathrm{pH} 3.5)$ compared to systems with other metal ions, where $[\mathrm{BeA}]^{+}$, $[\mathrm{ZnA}]^{+},[\mathrm{NiA}]^{+},[\mathrm{CoA}]^{+}$and $[\mathrm{MnA}]^{+}$species were found to form at $\mathrm{pH} 4.0,5.5,6.0,7.0$ and 7.5, respectively. Similarly, $\left[\mathrm{CuA}_{2}\right]$ species also started to form at $\mathrm{pH} 5.0$ and achieved about $95 \%$ of $\left[\mathrm{MA}_{2}\right]$ at $\mathrm{pH} 8.0$, while other metals started to form $\left[\mathrm{MA}_{2}\right]$ species at a higher $\mathrm{pH}\left(\sim 5.0,7.0,7.5,8.0\right.$ and 8.5 for $\left[\mathrm{BeA}_{2}\right],\left[\mathrm{ZnA}_{2}\right],\left[\mathrm{NiA}_{2}\right]$, $\left[\mathrm{CoA}_{2}\right]$ and $\left[\mathrm{MnA}_{2}\right]$, respectively).

A similar observation was also noticed in binary systems of the ligand D. As presented in Table 4, the largest stability value was obtained in the system containing $\mathrm{Cu}^{2+}\left(\log \beta_{\mathrm{CuD}}=13.77\right)$, followed by other metal-ligand systems $\left(\log \beta_{\mathrm{MD}}=13.52,8.71,8.06,7.76\right.$ and 7.36 for $\mathrm{Be}^{2+}, \mathrm{Zn}^{2+}, \mathrm{Ni}^{2+}, \mathrm{Co}^{2+}$ and $\mathrm{Mn}^{2+}$, respectively). Speciation diagrams of the binary systems containing ligand D (Fig. 7) confirm that these systems have at least two ligands attached to the metal ion. Ligand $\mathrm{D}$ begins to form $\left[\mathrm{MD}_{2}\right]^{4-}$ complexes at $\mathrm{pH}$ values of about 6.0, 7.0, 8.0, 9.0, 9.0 and 9.0 for systems containing $\mathrm{Cu}^{2+}, \mathrm{Be}^{2+}, \mathrm{Zn}^{2+}, \mathrm{Ni}^{2+}, \mathrm{Co}^{2+}$ and $\mathrm{Mn}^{2+}$, respectively.

In this work, the formation of complex species in a stepwise manner was also investigated. The log value of the stepwise association constants $\left(\log K_{\mathrm{ML} n}\right)$ were calculated from the following equations [27]:

$\mathrm{ML}_{n-1}+\mathrm{L} \leftrightarrow \mathrm{ML}_{n} \quad\left[\mathrm{ML}_{n}\right]=K_{\mathrm{ML} n}\left[\mathrm{ML}_{n-1}\right][\mathrm{L}]$

$\log K_{\mathrm{ML} n}=\log \beta_{\mathrm{MLn}}-\left(\log \beta_{\mathrm{MLn}-1}+\log \beta_{\mathrm{ML} n-2}+\ldots\right)$ where $\mathrm{L}$ refers to ligand $\mathrm{A}$ or $\mathrm{D}$, and the subscript $n$ denotes the number of ligands attached to the metal ion. It can be seen that the $\log K$ value of $\left[\mathrm{MA}_{2}\right]^{2-}$ species is smaller than that of [MA] species, for example $\log K_{\mathrm{CuA} 2}(6.36)<\log K_{\mathrm{CuA}}$ (8.48). A similar trend was also observed in the system containing ligand $\mathrm{D}\left(\log K_{\mathrm{ML} 3}<\right.$ $\log K_{\mathrm{ML} 2}<\log K_{\mathrm{ML}}$ ). Thus it can be concluded that the stepwise formation constant decreases with the increasing number of ligands attached to the metal ion. This phenomenon occurs possibly due to the reduction of the coordination number and the occurrence of steric effects at the metal ion after attachment of the first ligand.

Besides [ML], $\left[\mathrm{ML}_{2}\right]$ and $\left[\mathrm{ML}_{3}\right]$ species, it was also observed that at low $\mathrm{pH}$, both ligand $\mathrm{A}$ and $\mathrm{D}$ may form a complex with $\mathrm{Cu}^{2+}$ and $\mathrm{Be}^{2+}$ in the protonated form, $\left[\mathrm{MLH}_{n}\right]$. From the species distribution diagrams (Figs. 6 and 7), it is obvious that $[\mathrm{CuAH}]^{2+}$ and $[\mathrm{BeAH}]^{2+}$ species can be found between $\mathrm{pH} 2$ and 6 , while the species $\left[\mathrm{CuDH}_{2}\right]^{+},[\mathrm{CuDH}]$ and $[\mathrm{BeDH}]$ can be found between $\mathrm{pH} 3.0$ and 8.0. The $\log K$ value of the $\left[\mathrm{MLH}_{n}\right]$ species was found to be smaller than the $\log K$ value of the $[\mathrm{ML}]$ species $\left(\log K_{\mathrm{CuAH}}=3.03\right.$; $\log K_{\mathrm{BeAH}}=3.50 ; \quad \log K_{\mathrm{CuDH}}=6.34 ; \quad \log K_{\mathrm{CuDH} 2}=2.57$; $\left.\log K_{\mathrm{BeDH}}=6.85\right)$. This confirms the basic theory that complexation of a bidentate ligand with a five-membered ring gives better stability, since the formation tendency achieves more by the enthalpy effect than by the entropy effect $[39,40]$. This greater enthalpy effect increases the crystal field strength, which means it increases the point of attachment of the ligand to the metal ion, imparting a higher chelating tendency to the latter $[39,40]$. Since the $\left[\mathrm{MLH}_{n}\right]$ species has a significantly weaker stability than the [ML] species, in the systems with less stable [ML] species, particularly the systems that contain $\mathrm{Zn}^{2+}, \mathrm{Ni}^{2+}, \mathrm{Co}^{2+}$ and $\mathrm{Mn}^{2+}$, the $\left[\mathrm{MLH}_{n}\right]$ species did not appear in the early $\mathrm{pH}$ range.

According to the observations, both ligands A and D form complexes with divalent metal ions in a similar manner. The overall result shows that the stabilities of the binary ligand-metal system decrease in the following order: $\mathrm{Cu}^{2+}>\mathrm{Be}^{2+}>\mathrm{Zn}^{2+}>\mathrm{Ni}^{2+}>\mathrm{Co}^{2+}>$ $\mathrm{Mn}^{2+}$. This trend in stability constants coincides with the order in the magnitude of the buffer region shifting, shown in Fig. 5. Moreover, this stability order agrees with the Irving-William series [41] and the results of Ahrland et al. [42], where a-type metals, including the divalent metals used in this study, will form stable complexes with ligands that possess $\mathrm{N}, \mathrm{O}$ and $\mathrm{F}$ atoms as the coordinating binding site. However, in terms of coordination ability, the binary systems with ligand A showed less stable coordination than the systems involving ligand D.

\subsection{Ternary system of metal-ligand complexes}

The obtained protonation constants of the ligands A and D, along with their complex stability constants with metal ions $\left(\mathrm{Cu}^{2+}, \mathrm{Be}^{2+}, \mathrm{Zn}^{2+}, \mathrm{Ni}^{2+}, \mathrm{Co}^{2+}\right.$ and $\left.\mathrm{Mn}^{2+}\right)$ in the binary systems were introduced into the Hyperquad2008 program for determination of the stability constants of complexes in ternary systems. The refinement results are presented as the overall formation constants $\left(\log \beta_{\text {MpAqDrHs }}\right)$ in Table 5 .

Again, the results suggest that the system with $\mathrm{Cu}^{2+}$ has the highest stability among all the ternary systems studied. The overall stability of the complex formed by the metal ion with two ligands $\left(\log \beta_{\text {MAD }}\right)$ decreases in a similar order as that in the binary system: $\mathrm{Cu}^{2+}>\mathrm{Be}^{2+}>\mathrm{Zn}^{2+}>\mathrm{Ni}^{2+}>\mathrm{Co}^{2+}>\mathrm{Mn}^{2+}$. The stability constant values were supported by the refinement from the spectrophotometric method using Hypspec, where the value differences are very small from the Hyperquad refinement results. These obtained stability constants of complex species in both binary and ternary systems then were used as the input in the HySS2009 program to predict the distribution of the involved species within the experimental pH range (Fig. 8). It turns out that most metal ions in the ternary systems started to form MADH at almost the same $\mathrm{pH}$ 

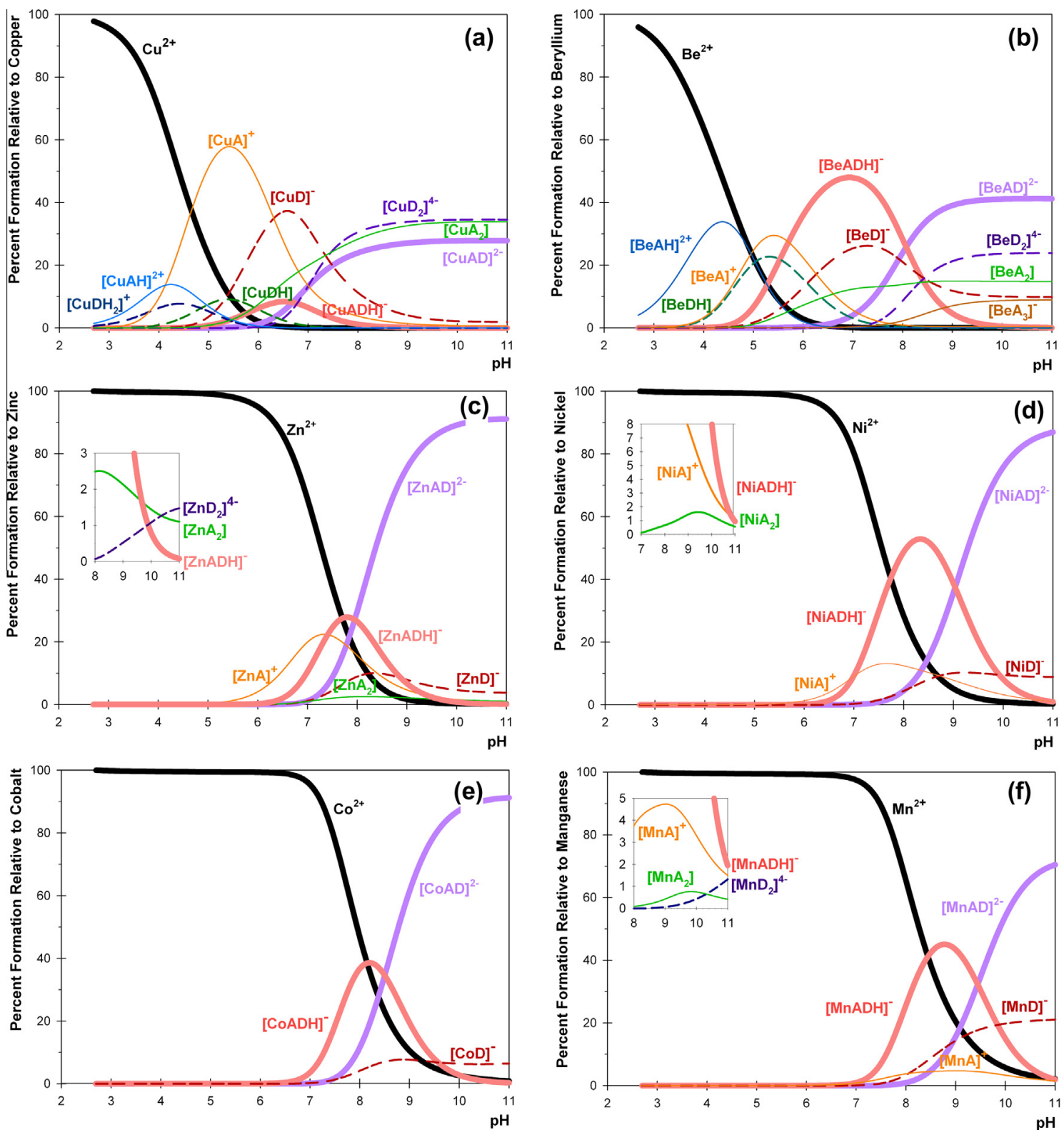

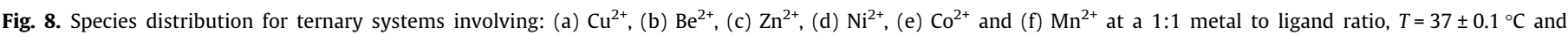
$I=0.15 \mathrm{~mol} \mathrm{dm}^{-3} \mathrm{NaCl}$

where the coordination of the binary ligand D began. The formation was quite small, but it played a role in initiating the formation of the ternary complex (MAD).

Fig. 8 also shows that ligand A coordinated to metal ions and formed $[\mathrm{MAH}]$ or $[\mathrm{MA}]$ species at a lower $\mathrm{pH}$ than ligand $\mathrm{D}$, which suggests that ligand $A$ acted as the primary chelating compound in the systems. This is because amino group $\left(-\mathrm{NH}_{2}\right)$ in ligand A makes it a hard Lewis base which leads to early deprotonation. At higher $\mathrm{pH}$, some metal-ligand A complexes appeared to lose their coordination, leading to the formation of metal-ligand D. This ligand substitution process was expected since in the binary system studies ligand D showed larger stability constant values which suggests stronger metal-ligand coordination than for ligand A. Therefore, the interaction of the metal with the primary ligand was initiated at the beginning, then coordination of these donor groups was replaced by the secondary ligand (ligand D).

Spectral measurements for all ternary systems involving one divalent metal ions $\left(\mathrm{Cu}^{2+}, \mathrm{Be}^{2+}, \mathrm{Zn}^{2+}, \mathrm{Ni}^{2+}, \mathrm{Co}^{2+}\right.$ or $\left.\mathrm{Mn}^{2+}\right)$ and two ligands (A and D) have been performed in the UV-Vis range wavelength and the results are given in Table 6 . The spectral bands were observed at an initial pH of 2.5 and pH 11.0, where at pH 11.0 the formation of MAD species was observed at the highest concentration, based on the speciation diagram. The observed change in the spectral bands also confirmed the formation of the MAD complex in the system.

At an initial pH of 2.5 some peaks were observed: (1) the aromatic ring of the ligand gives a spectrum which was observed at $210-244 \mathrm{~nm}$; (2) the observed band at 260-267 nm for all systems refers to the $\pi-\pi^{*}$ electronic transition of the 0 donor atom from the ligand $\mathrm{D}$ to the metal ion, while the $\mathrm{N}$ donor atom from ligand A give rises to a band at 298-312 nm - both ligands used are weak field ligands, in which the ligand donates an electron to bind with the metal ion; (3) the $d-d$ transition band of the metal ion was clearly observed at the initial $\mathrm{pH}$ since the free metal ion was still of a high concentration. For $\mathrm{Cu}^{2+}\left(\mathrm{d}^{9}\right)$ the bands observed at 414 and $620 \mathrm{~nm}$ are due to the electronic transitions ${ }^{2} \mathrm{~A}_{1 \mathrm{~g}} \rightarrow{ }^{2} \mathrm{~B}_{1 \mathrm{~g}}$ and 
Table 6

UV-Vis data of ternary systems involving several metals.

\begin{tabular}{|c|c|c|c|}
\hline \multirow[t]{2}{*}{ Metal ions } & \multicolumn{2}{|l|}{$\lambda_{\max }(\mathrm{nm})$} & \multirow[t]{2}{*}{ Assignment } \\
\hline & $\mathrm{pH} 2.5$ & pH 11.0 & \\
\hline $\mathrm{Cu}^{2+}$ & $\begin{array}{l}210-239 \\
266 \\
301 \\
414 \\
620\end{array}$ & $\begin{array}{l}211-241 \\
270 \\
316 \\
440 \\
-\end{array}$ & $\begin{array}{l}\text { aromatic ring } \\
\pi-\pi^{*} \\
\pi-\pi^{*} \\
{ }^{2} \mathrm{~A}_{1 \mathrm{~g}} \rightarrow{ }^{2} \mathrm{~B}_{1 \mathrm{~g}} \\
{ }^{2} \mathrm{E}_{\mathrm{g}} \rightarrow{ }^{2} \mathrm{~B}_{1 \mathrm{~g}}\end{array}$ \\
\hline $\mathrm{Be}^{2+}$ & $\begin{array}{l}210-238 \\
266 \\
300 \\
436\end{array}$ & $\begin{array}{l}211-238 \\
275 \\
308 \\
444\end{array}$ & $\begin{array}{l}\text { aromatic ring } \\
\pi-\pi^{*} \\
\pi-\pi^{*} \\
\text { red shifting }\end{array}$ \\
\hline $\mathrm{Zn}^{2+}$ & $\begin{array}{l}212-239 \\
260 \\
312 \\
439\end{array}$ & $\begin{array}{l}212-240 \\
264 \\
319 \\
442\end{array}$ & $\begin{array}{l}\text { aromatic ring } \\
\pi-\pi^{*} \\
\pi-\pi^{*} \\
\text { red shifting }\end{array}$ \\
\hline $\mathrm{Ni}^{2+}$ & $\begin{array}{l}210-237 \\
267 \\
298 \\
446 \\
521\end{array}$ & $\begin{array}{l}210-241 \\
274 \\
300 \\
451 \\
-\end{array}$ & $\begin{array}{l}\text { aromatic ring } \\
\pi-\pi^{*} \\
\pi-\pi^{*} \\
{ }^{3} \mathrm{~A}_{2 \mathrm{~g}}(\mathrm{~F}) \rightarrow{ }^{3} \mathrm{~T}_{1 \mathrm{~g}}(\mathrm{P}) \\
{ }^{3} \mathrm{~A}_{2 \mathrm{~g}}(\mathrm{~F}) \rightarrow{ }^{3} \mathrm{~T}_{1 \mathrm{~g}}(\mathrm{~F})\end{array}$ \\
\hline $\mathrm{Co}^{2+}$ & $\begin{array}{l}211-244 \\
267 \\
299 \\
445 \\
654\end{array}$ & $\begin{array}{l}211-250 \\
270 \\
311 \\
436 \\
-\end{array}$ & $\begin{array}{l}\text { aromatic ring } \\
\pi-\pi^{*} \\
\pi-\pi^{*} \\
{ }^{4} \mathrm{~A}_{2 \mathrm{~g}}(\mathrm{~F}) \rightarrow{ }^{4} \mathrm{~T}_{1 \mathrm{~g}}(\mathrm{P}) \\
{ }^{4} \mathrm{~A}_{2 \mathrm{~g}}(\mathrm{~F}) \rightarrow{ }^{4} \mathrm{~T}_{1 \mathrm{~g}}(\mathrm{~F})\end{array}$ \\
\hline $\mathrm{Mn}^{2+}$ & $\begin{array}{l}210-239 \\
265 \\
310 \\
447\end{array}$ & $\begin{array}{l}211-250 \\
268 \\
307 \\
430\end{array}$ & $\begin{array}{l}\text { aromatic ring } \\
\pi-\pi^{*} \\
\pi-\pi^{*} \\
{ }^{6} \mathrm{~A}_{1 \mathrm{~g}}(\mathrm{~S}) \rightarrow{ }^{4} \mathrm{~T}_{1 \mathrm{~g}}(\mathrm{G})\end{array}$ \\
\hline
\end{tabular}

Table 7

The $\Delta \log K_{\mathrm{M}}$ and $\log X$ values of ternary systems involving 2-aminophenol (A) and 3,4dihydroxybenzoic acid (D).

\begin{tabular}{lcr}
\hline Metal ions & $\Delta \log K_{\mathrm{M}}$ & $\log X$ \\
\hline $\mathrm{Cu}^{2+}$ & -2.67 & -0.19 \\
$\mathrm{Be}^{2+}$ & -2.52 & 0.68 \\
$\mathrm{Zn}^{2+}$ & 0.33 & 3.31 \\
$\mathrm{Ni}^{2+}$ & 0.37 & 5.12 \\
$\mathrm{Co}^{2+}$ & 1.27 & 6.06 \\
$\mathrm{Mn}^{2+}$ & 0.67 & 3.96 \\
\hline
\end{tabular}

${ }^{2} \mathrm{E}_{\mathrm{g}} \rightarrow{ }^{2} \mathrm{~B}_{1 \mathrm{~g}}$, respectively. $\mathrm{Be}^{2+}\left(\mathrm{s}^{2}\right)$ and $\mathrm{Zn}^{2+}\left(\mathrm{d}^{10}\right)$ were found not to have any orbital transition. The observed bands at 446 and $521 \mathrm{~nm}$ for $\mathrm{Ni}^{2+}\left(\mathrm{d}^{8}\right)$ are attributed to the transitions ${ }^{3} \mathrm{~A}_{2 \mathrm{~g}}(\mathrm{~F}) \rightarrow{ }^{3} \mathrm{~T}_{1 \mathrm{~g}}(\mathrm{P})$ and ${ }^{3} \mathrm{~A}_{2 \mathrm{~g}}(\mathrm{~F}) \rightarrow{ }^{3} \mathrm{~T}_{1 \mathrm{~g}}(\mathrm{~F})$, respectively. For $\mathrm{Co}^{2+}\left(\mathrm{d}^{7}\right)$, the orbital transition ${ }^{4} \mathrm{~A}_{2 \mathrm{~g}}(\mathrm{~F}) \rightarrow{ }^{4} \mathrm{~T}_{1 \mathrm{~g}}(\mathrm{P})$ was observed at $445 \mathrm{~nm}$, while the transition ${ }^{4} \mathrm{~A}_{2 \mathrm{~g}}(\mathrm{~F}) \rightarrow{ }^{4} \mathrm{~T}_{1 \mathrm{~g}}(\mathrm{~F})$ was observed at $654 \mathrm{~nm}$. For $\mathrm{Mn}^{2+}\left(\mathrm{d}^{5}\right)$, the transition ${ }^{6} \mathrm{~A}_{1 \mathrm{~g}}(\mathrm{~S}) \rightarrow{ }^{4} \mathrm{~T}_{1 \mathrm{~g}}(\mathrm{G})$ was observed at $447 \mathrm{~nm}$.

At $\mathrm{pH}$ 11.0, the MAD species in all systems were found in high concentration and caused a shifting of the bands. The changes of the spectra were observed as follows: (1) the aromatic ring band shifts to higher wavelength $(210-250 \mathrm{~nm})$; (2) the band corresponding to the $\pi-\pi^{*}$ electronic transition of the $O$ donor atom of the ligand shifts to $264-275 \mathrm{~nm}$, while the band corresponding to the $\mathrm{N}$ donor atom shifts to $300-316 \mathrm{~nm}$; (3) shifts for the electronic transitions of the metal ions. For $\mathrm{Cu}^{2+}\left(\mathrm{d}^{9}\right)$, the band for the ${ }^{2} \mathrm{~A}_{1 \mathrm{~g}} \rightarrow{ }^{2} \mathrm{~B}_{1 \mathrm{~g}}$ transition shifts to $440 \mathrm{~nm}$, while the band of ${ }^{2} \mathrm{E}_{\mathrm{g}} \rightarrow{ }^{2} \mathrm{~B}_{1 \mathrm{~g}}$ disappears. For $\mathrm{Ni}^{2+}\left(\mathrm{d}^{8}\right)$, the band attributed to the transition ${ }^{3} \mathrm{~A}_{2 \mathrm{~g}}(\mathrm{~F}) \rightarrow{ }^{3} \mathrm{~T}_{1 \mathrm{~g}}(\mathrm{P})$ shifts to $451 \mathrm{~nm}$ and the other band also disappears. For $\mathrm{Co}^{2+}\left(d^{7}\right)$, the orbital transition ${ }^{4} \mathrm{~A}_{2 \mathrm{~g}}(\mathrm{~F}) \rightarrow{ }^{4} \mathrm{~T}_{1 \mathrm{~g}}(\mathrm{P})$ shifts to a lower wavelength $(436 \mathrm{~nm})$. For $\mathrm{Mn}^{2+}\left(\mathrm{d}^{5}\right)$, the transition ${ }^{6} \mathrm{~A}_{1 \mathrm{~g}}(\mathrm{~S}) \rightarrow{ }^{4} \mathrm{~T}_{1 \mathrm{~g}}(\mathrm{G})$ also shifts to a lower wavelength (447 nm). Some of the $d-d$ transition bands disappear, possibly due to their low intensity, the bands being overlapped by the ligand donor band which has a higher intensity.

Further analysis of the complexation equilibria in the ternary systems was done by calculating $\Delta \log K_{\mathrm{M}}$ (Eq. (5)), which is the relative stability of the ternary complex (MAD) compared to the complex stability in the corresponding binary system (MA and MD) [43].

$\Delta \log K_{M}=\log K_{\mathrm{MAD}}^{\mathrm{MA}}-\log \beta_{\mathrm{MD}}=\log K_{\mathrm{MAD}}^{\mathrm{MD}}-\log K_{\mathrm{MA}}$

A positive value of $\Delta \log K_{\mathrm{M}}$ indicates the tendency of the metal to form a ternary complex rather than a binary complex [44]. The calculated $\Delta \log K_{\mathrm{M}}$ values of ternary systems involving ligand $\mathrm{A}$, ligand $\mathrm{D}$ and several divalent metal ions $\left(\mathrm{Cu}^{2+}, \mathrm{Be}^{2+}, \mathrm{Zn}^{2+}, \mathrm{Ni}^{2+}\right.$, $\mathrm{Co}^{2+}$ and $\mathrm{Mn}^{2+}$ ) are given in Table 7. From this table, it can be seen that the $\Delta \log K_{\mathrm{M}}$ values for all the systems are negative. These values indicate that formation of a binary metal complex (MA or MD) is preferred over that of the ternary complex (MAD). One possible reason is the occurrence of steric hindrance, where attachment of the primary ligand to the metal ion increases the bulkiness of the complex structure. Thus it prevents the secondary ligand from coordinating and forming a ternary complex. Besides, the secondary ligand has less of a chance to interact with the chelated-metal ion due to reduction of the coordination sites at the metal ion and electrostatic effect between the metal and secondary ligand.

It is also observed that some divalent metal ions which show a higher stepwise stability with ligand $\mathrm{D}\left(\log \beta_{\mathrm{MD}}\right)$ tend to have a more negative $\Delta \log K_{\mathrm{M}}$. The order of stability in the binary system (both $\log \beta_{\mathrm{MD}}$ or $\log \beta_{\mathrm{MA}}$ ) was found to be almost opposite to the order of $\Delta \log K_{\mathrm{M}}\left(\mathrm{Co}^{2+}>\mathrm{Mn}^{2+}>\mathrm{Ni}^{2+}>\mathrm{Zn}^{2+}>\mathrm{Be}^{2+}>\mathrm{Cu}^{2+}\right)$. It suggests that the formation of stable ternary complexes is more difficult in systems with a very stable binary complex. However, once a ternary complex is formed, it has greater stability than those of the binary systems.

The stability of ternary complexes can also be quantitatively analyzed by their $\log X$ values, which were calculated using Eq. (6). This parameter was used to predict the tendency of one mole of the binary complex $\mathrm{MA}_{2}$ and one mole of the binary complex $\mathrm{MD}_{2}$ to form two moles of the ternary complex MAD $[45,46]$.

$\mathrm{MA}_{2}+\mathrm{MD}_{2} \leftrightarrow 2 \mathrm{MAD}$

The results for $\log X$ are given in Table 7. Positive values of $\log X$ were found for most metal ions, which suggests that the formation of ternary complexes containing two different ligands (MAD) is more favorable than complexes with two similar ligands $\left(\mathrm{MA}_{2}\right.$ or $\mathrm{MD}_{2}$ ). Formation of a ternary complex containing two similar ligands $\left(\mathrm{MA}_{2}\right.$ or $\left.\mathrm{MD}_{2}\right)$ has greater strain of coordination, thus the system prefers to form ternary complexes with different ligands (MAD). In contrast, the $\mathrm{Cu}^{2+}$ ion was the only metal ion that gave a negative value, which means it also has a strong tendency to form $\mathrm{MA}_{2}$ or $\mathrm{MD}_{2}$ complexes. As shown in Fig. $8, \mathrm{CuA} \mathrm{A}_{2}$ and $\mathrm{CuD}_{2}$ were stable and formed together along with CuAD.

\section{Conclusions}

Two chelating agents, 2-aminophenol (ligand A) and 3,4-dihydroxybenzoic acid (ligand D), were employed in this work to study the complex formation of these ligands with divalent metal ions $\left(\mathrm{Cu}^{2+}, \mathrm{Be}^{2+}, \mathrm{Zn}^{2+}, \mathrm{Ni}^{2+}, \mathrm{Co}^{2+}\right.$ and $\left.\mathrm{Mn}^{2+}\right)$ at $37^{\circ} \mathrm{C}$ and with an ionic strength of $0.15 \mathrm{~mol} \mathrm{dm}^{-3} \mathrm{NaCl}$. Ligand A possesses an amino group $\left(-\mathrm{NH}_{2}\right)$ and a hydroxyl group $(-\mathrm{OH})$ that were protonated at $\log K 4.53$ and 9.58 , respectively. In contrast, ligand $\mathrm{D}$ has three protonation sites, occurring at $\log K 4.42,8.62$, and 12.75 , which correspond to the carboxylic, para-hydroxyl and meta-hydroxyl groups, respectively. 
Divalent metal ions, forming binary complexes with ligands A or/and $\mathrm{D}$ in both binary and ternary systems, have stability in the following order: $\mathrm{Cu}^{2+}>\mathrm{Be}^{2+}>\mathrm{Zn}^{2+}>\mathrm{Ni}^{2+}>\mathrm{Co}^{2+}>\mathrm{Mn}^{2+}$. This order is in agreement with the buffer region shifting that occurred in potentiometric titration curves, where the furthest and closest shifting can be seen in systems containing $\mathrm{Cu}^{2+}$ and $\mathrm{Mn}^{2+}$, respectively. Based on its overall formation constant values, ligand D showed a better chelating ability with metal ions than ligand A. However, based on speciation diagrams of the complexes in the ternary systems, it is suggested that ligand A acted as the primary ligand in these systems and was coordinated to metal ions at lower $\mathrm{pH}$.

Investigations of the stability of the ternary complexes relative to their corresponding binary complexes were also carried out in this work by calculating $\Delta \log K_{\mathrm{M}}$ and $\log X$ values. Negative values of $\Delta \log K_{\mathrm{M}}$ were obtained in all the systems studied, which indicated that formation of binary metal complexes (MA or MD) is more preferable than formation of ternary complexes (MAD). However, larger values of $\log \beta_{\text {MAD }}$ compared to $\log \beta_{\mathrm{MA}}$ and $\log \beta_{\mathrm{MD}}$ suggests that the metal-ligand complexes that are formed in the ternary systems have greater stability than those of the binary systems. On the other hand, calculation of $\log X$ gave positive values for most metal ions studied, which indicates that the formation of ternary complexes containing two different ligands (MAD) is more preferable than complexes involving two similar ligands $\left(\mathrm{MA}_{2}\right.$ or $\left.\mathrm{MD}_{2}\right)$.

\section{Acknowledgements}

Financial support by the National Science Council of Taiwan (NSC 102-2221-E-011-079) and the National Taiwan University of Science and Technology (101H451403) is greatly appreciated.

\section{References}

[1] S.J.S. Flora, V. Pachauri, Int. J. Environ. Res. Public Health 7 (2010) 2745.

[2] S.J.S. Flora, M. Mittal, A. Mehta, Ind. J. Med. Res. 128 (2008) 501.

[3] C.R. Baum, Curr. Opin. Pediatr. 11 (1999) 265.

[4] B. Guldager, P.J. Jorgensen, P. Grandjean, Clin. Chem. 42 (1996) 1938.

[5] L. Fournier, G. Thomas, R. Garnier, A. Buisine, P. Houze, F. Pradier, Med. Toxicol. 3 (1988) 499.

[6] R. Peters, L. Stocken, R. Thompson, Nature 156 (1945) 616.

[7] C.D. Klaassen, in: L. Goodman, A. Gilman (Eds.), The Pharmacological Basis of Therapeutics, McGraw Hill, New York, 2006, p. 1825.

[8] O. Andersen, Chem. Rev. 99 (1999) 2683.
[9] K. Grasedyck, Z. Rheumatol. 47 (1988) 17.

[10] P. Pachauri, G. Saxena, A. Mehta, D. Mishra, S.J.S. Flora, Toxicol. Appl Pharmacol. 240 (2009) 255

[11] S.J.S. Flora, M. Pande, A. Mehta, Chem. Biol. Interact. 145 (2003) 267.

[12] M. Pande, S.J.S. Flora, Toxicology 177 (2002) 187.

[13] D. Mishra, S.J.S. Flora, Biol. Trace Elem. Res. 122 (2008) 137.

[14] A. Škríba, S. Janková, J. Váňa, P. Barták, P. Bednář, P. Fryčák, L. Kučera, O. Kurka, K. Lemr, P. Macíková, E. Marková, P. Nováková, B. Papoušková, J. Skopalová, H. Švecová, J. Roithová, Int. J. Mass Spectrom. 337 (2013) 18.

[15] B. Mary, G.A.D. Haslewood, Br. Med. J. 2 (1944) 754

[16] B. Mary, G.A.D. Haslewood, Biochemistry 39 (1945) 285.

[17] R.T. Williams, Biochem. J. 32 (1938) 878.

[18] T.H. Tseng, J.D. Hsu, M.H. Lo, C.Y. Chu, F.P. Chou, C.L. Huang, C.J. Wang, Cancer Lett. 126 (1998) 199.

[19] T. Tanaka, T. Kawamori, M. Ohnishi, K. Okamoto, H. Mori, A. Hara, Cancer Res. 54 (1994) 2359.

[20] R. Suzuki, H. Kohno, S. Sugie, T. Tanaka, Asian Pac. J. Cancer Prev. 4 (2003) 319.

[21] G.I. Panoutsopoulos, C. Beedham, Cell Physiol. Biochem. 15 (2005) 89.

[22] G. Schmeda-Hirschmann, A. Tapia, C. Theoduloz, J. Rodriguez, S. Lopez, G.E. Feresin, Z. Naturforsch. C 59 (2004) 345.

[23] P. Gans, B. O'Sullivan, Talanta 51 (2000) 33.

[24] P. Gans, A. Sabatini, A. Vacca, Talanta 43 (1996) 1739.

[25] A. Braibanti, G. Ostacoli, P. Paoletti, L.D. Pettit, S. Sammartano, Pure Appl. Chem. 59 (1987) 1721.

[26] D.P. Mellor, in: F. Dwyer (Ed.), Chelating Agents and Metal Chelates, Elsevier, Academic Press, New York, 1964, p. 1.

[27] J. Bjerrum, Metal Ammine Formation in Aqueous Solution: Theory of the Reversible Step Reactions, P. Haase and Son, Denmark, 1941.

[28] L. Alderighi, P. Gans, A. Lenco, D. Peters, A. Sabatini, A. Vacca, Coord. Chem. Rev. 184 (1999) 311.

[29] A.E. Martell, R.M. Smith, Critical Stability Constants, Second Supplement, Plenum Press, New York, 1989.

[30] K. Zavitsanos, K. Tampouris, A.L. Petrou, Bioinorg. Chem. Appl. 2008 (2008) 1.

[31] P. Dasgupta, R.B. Jordan, Inorg. Chem. 24 (1985) 2717.

[32] A. Galano, A.P. González, Theor. Chem. Acc. 131 (2012) 1265.

[33] C.T. Abichandani, S.K.K. Jatkar, J. Indian Inst. Sci. 21A (1938) 417.

[34] D. Hatzipanayioti, A. Karaliota, M. Kamariotaki, V. Aletras, P. Petropouleas, Chem. Phys. 325 (2006) 341.

[35] L.D. Pettit, H.K.J. Powell, IUPAC Stability Constants Database, Royal Society of Chemistry, Academic Software, Timble, 2003.

[36] R.G. Pearson, J. Chem. Educ. 45 (1968) 581.

[37] K.A. Walsh, E. Dalder, A. Goldberg, D.L. Olson, E.E. Vidal, Beryllium Chemistry and Processing, ASM International, Ohio, 2009.

[38] W. Raith, T. Mulvey, Constituents of Matter: Atoms, Molecules, Nuclei, and Particles, CRC Press, London, 2001.

[39] G. Schwarzenbach, Helv. Chim. Acta 35 (1952) 2344.

[40] A.W. Adamson, J. Am. Chem. Soc. 76 (1954) 1578.

[41] H. Irving, R.J.P. Williams, J. Chem. Soc. (1953) 3192

[42] S. Ahrland, J. Chatt, N.R. Davies, J. Chem. Soc. (1958) 264.

[43] H. Sigel, Coordination Chemistry, Pergamon Press, Oxford, 1980.

[44] M.M. Khalil, A.E. Radalla, F. Qasem, R. Khaled, Korean J. Chem. Eng. 31 (2014) 109.

[45] R.B. Martin, P. Prados, J. Inorg. Nucl. Chem. 36 (1974) 1665.

[46] R.B. Martin, Metal Ions in Biological Systems, Marcel Dekker, New York, 1979. 